\title{
Software Interface Assessment of the Centralized Aviation Flight Records System (CAFRS) 4.0
}

by Gina A Pomranky-Hartnett, David B Durbin, and Jamison S Hicks 


\section{NOTICES}

\section{Disclaimers}

The findings in this report are not to be construed as an official Department of the Army position unless so designated by other authorized documents.

Citation of manufacturer's or trade names does not constitute an official endorsement or approval of the use thereof.

Destroy this report when it is no longer needed. Do not return it to the originator. 


\section{Army Research Laboratory}

Aberdeen Proving Ground, MD 21005-5425

ARL-TR-7289

May 2015

\section{Software Interface Assessment of the Centralized Aviation Flight Records System (CAFRS) 4.0}

Gina A Pomranky-Hartnett, David B Durbin, and Jamison S Hicks

Human Research and Engineering Directorate, ARL 


\section{REPORT DOCUMENTATION PAGE}

Public reporting burden for this collection of information is estimated to average 1 hour per response, including the time for reviewing instructions, searching existing data sources, gathering and maintaining the data needed, and completing and reviewing the collection information. Send comments regarding this burden estimate or any other aspect of this collection of information, including suggestions for reducing the burden, to Department of Defense, Washington Headquarters Services, Directorate for Information Operations and Reports (0704-0188), 1215 Jefferson Davis Highway, Suite 1204, Arlington, VA 22202-4302. Respondents should be aware that notwithstanding any other provision of law, no person shall be subject to any penalty for failing to comply with a collection of information if it does not display a currently valid OMB control number.

PLEASE DO NOT RETURN YOUR FORM TO THE ABOVE ADDRESS.

\begin{tabular}{l|l}
$\begin{array}{ll}\text { 1. REPORT DATE }(D D-M M-Y Y Y Y) \\
\text { May } 2015\end{array}$ & $\begin{array}{l}\text { 2. REPORT TYPE } \\
\text { Final }\end{array}$ \\
\hline $\begin{array}{l}\text { 4. TITLE AND SUBTITLE } \\
\text { Software Interface Assessment of the Centralized Aviation Flight Records System } \\
\text { (CAFRS) } 4.0\end{array}$
\end{tabular}

(CAFRS) 4.0

3. DATES COVERED (From - To)

October 2013-September 2014

5a. CONTRACT NUMBER

5b. GRANT NUMBER

5c. PROGRAM ELEMENT NUMBER

6. AUTHOR(S)

Gina A Pomranky-Hartnett, David B Durbin, and Jamison S Hicks

5d. PROJECT NUMBER

62716АH70

5e. TASK NUMBER

5f. WORK UNIT NUMBER

7. PERFORMING ORGANIZATION NAME(S) AND ADDRESS(ES)

8. PERFORMING ORGANIZATION

REPORT NUMBER

US Army Research Laboratory

ATTN: RDRL-HRM-DJ

ARL-TR-7289

Aberdeen Proving Ground, MD 21005-5425

9. SPONSORING/MONITORING AGENCY NAME(S) AND ADDRESS(ES)

Program Executive Office Aviation

Redstone Arsenal, AL 35898

PEO Aviation

11. SPONSOR/MONITOR'S REPORT

$\operatorname{NUMBER}(\mathbf{S})$

\section{DISTRIBUTION/AVAILABILITY STATEMENT}

Approved for public release; distribution is unlimited.

13. SUPPLEMENTARY NOTES

\section{ABSTRACT}

The US Army Research Laboratory's Human Research and Engineering Directorate (ARL/HRED) conducted a software interface assessment of the Centralized Aviation Flight Records System (CAFRS) version 4.0. The assessment was performed to identify CAFRS software design features (e.g., menu screen navigation) that enhanced or degraded user performance. CAFRS is used to manage Army aviation flight and air traffic services records that contain information such as the number of flight hours that pilots have flown and status of pilot and unit flight training requirements. CAFRS provides the Army's seniorlevel leadership with aviation flight operations information to assist in resource, readiness, and personnel management.

Participants were able to effectively use CAFRS to maintain aviation flight records and quickly complete most tasks during the assessment. Software interface and functionality problems were reported by the participants and addressed by the software developers. ARL/HRED will assess future CAFRS versions to enhance the software interface.

15. SUBJECT TERMS

Centralized Aviation Flight Records System, CAFRS, flight records, human factors, aviation software interface

\begin{tabular}{|l|l|l|c|c|l|}
\hline \multicolumn{2}{|l|}{ 16. SECURITY CLASSIFICATION OF: } & $\begin{array}{l}\text { 17. LIMITATION } \\
\text { OF ABSTRACT }\end{array}$ & $\begin{array}{l}\text { 18. NUMBER } \\
\text { OF PAGES }\end{array}$ & $\begin{array}{l}\text { 19a. NAME OF RESPONSIBLE PERSON } \\
\text { Gina A Pomranky-Hartnett }\end{array}$ \\
\cline { 1 - 2 } $\begin{array}{l}\text { a. REPORT } \\
\text { Unclassified }\end{array}$ & $\begin{array}{l}\text { b. ABSTRACT } \\
\text { Unclassified }\end{array}$ & $\begin{array}{l}\text { c. THIS PAGE } \\
\text { Unclassified }\end{array}$ & UU & 38 & $\begin{array}{l}\text { 19b. TELEPHONE NUMBER (Include area code) } \\
334-255-2135\end{array}$ \\
\hline
\end{tabular}




\section{Contents}

List of Figures $\quad$ iv

List of Tables $\quad$ iv

1. Introduction $\quad 1$

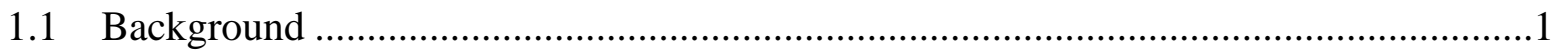

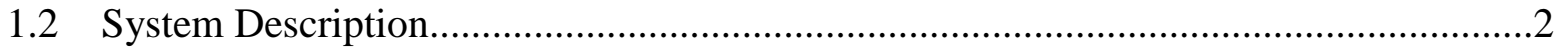

2. Method $\quad 9$

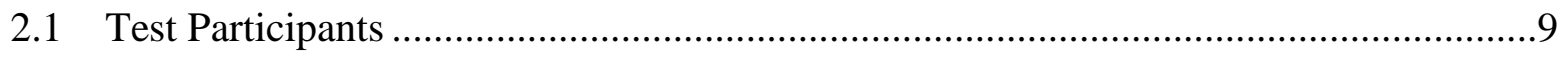

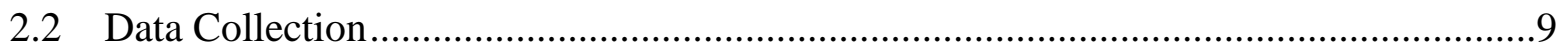

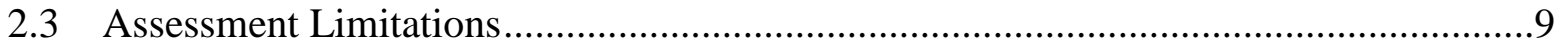

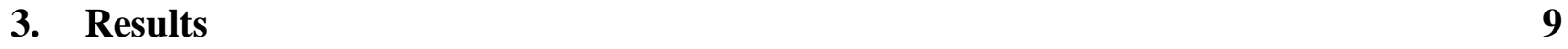

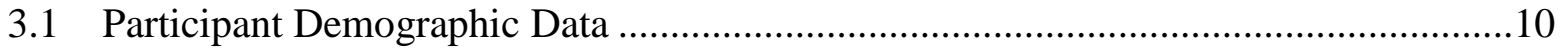

3.2 CAFRS Software User Interface Assessment ......................................................11

4. Conclusions $\quad 21$

4.1 CAFRS v4.0 Software Interface ................................................................21

4.2 Task Completion Rates and Tasks Times ........................................................21

$\begin{array}{lr}\text { 5. } & \text { References } \\ \end{array}$

$\begin{array}{ll}\text { Appendix. CAFRS v4.0 UTE } 1 \text { Trouble Reports } & 23\end{array}$

List of Symbols, Abbreviations, and Acronyms $\quad 29$

$\begin{array}{ll}\text { Distribution List } & 30\end{array}$ 


\section{List of Figures}

Fig. 1 CAFRS architecture............................................................................................

Fig. 2 CAFRS FORSCOM local database architecture ....................................................4

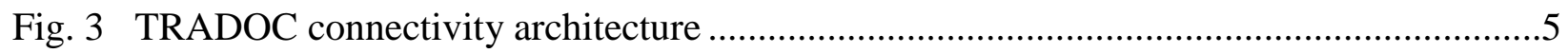

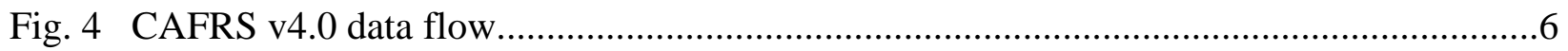

Fig. 5 Commander's task list ................................................................................... 7

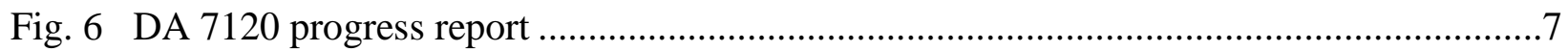

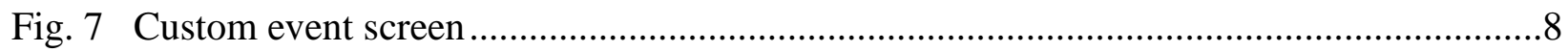

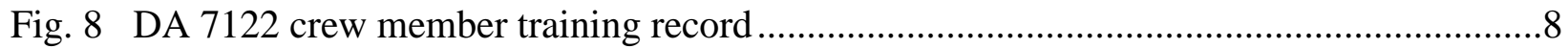

\section{List of Tables}

Table 1 CAFRS software user interface assessment results ..................................................12

Table 2 CAFRS software user interface assessment results .................................................14

Table 3 UTE 1 task pass/fail and completion times ..........................................................19

Table 4 UTE 2 task pass/fail and completion times ........................................................20 


\section{Introduction}

\subsection{Background}

The Centralized Aviation Flight Records System (CAFRS) is used to manage US Army aviation flight and air traffic services (ATS) records that contain information such as the number of flight hours that pilots have flown and status of pilot and unit flight training requirements. The records are managed in accordance with regulations and policies through a centralized, automated, globally accessible, and secure system. CAFRS provides the Army's senior-level leadership with aviation flight operations information to assist in resource, readiness, and personnel management. Commanders have access to essential aviation information to accomplish risk assessment and risk management throughout the aviation mission planning process.

The US Army Research Laboratory's Human Research and Engineering Directorate (ARL/HRED) conducted a software interface assessment of CAFRS version 4.0 (v4.0) during User Test Event (UTE) 1 and UTE 2 at the Aviation Networks and Mission Planning software development facility at Huntsville, AL. UTE 1 was conducted 29 April-2 May 2013 and UTE 2 was conducted 5-8 August 2013. These assessments were performed to identify CAFRS software design features that enhanced or degraded user performance. The following items were evaluated:

- Software menu architecture

- Number of steps required to complete data entry tasks

- Help functions

- Menu navigation

- Error messages

- Logic and intuitiveness of the menu screens

- How quickly v4.0 operated on the host computer

- Comparison of v4.0 with v3.0.3

- Time to complete tasks

- Task pass/fail rates

The assessments supported the CAFRS material release process and led to improvements in the software interface. 
ARL/HRED also conducted a software interface assessment of CAFRS v3.0 UTE (in 2009) and v3.0.2 software interface UTE (in 2010). The data collection methodology for each assessment during the UTEs was very similar, to allow comparisons of the software interface for each successive version. The results of the v3.0 and v3.0.2 assessments led to improvements in the software interface. ARL/HRED will assess future versions of CAFRS to improve the software interface and functionality.

\subsection{System Description}

CAFRS standardizes the process of compiling, tracking, and analyzing flight records and ATS records. This is accomplished by storing information in a centralized repository that can be accessed by the Internet. Internet accessibility provides visibility of unit and individual flight data as well as certification and qualification data above the unit level.

CAFRS augments the Army's ability to more accurately track and control aviator flight and training records, air traffic control (ATC) training records, and unmanned aircraft system (UAS) operators' hours. The CAFRS design requirement is to have a user-friendly software interface while reducing man-hours and recording errors through automation.

CAFRS replaced 3 legacy systems used for maintaining aircrew flight records: the DOS (Microsoft Disk Operating System)-based Automated Flight Records System (AFRS), Aviation Center Flight Records System (ACFRS), and the Unit Level Logistics System-Aviation (ULLS-A) flight operations module for aircrew flight records.

CAFRS is a Microsoft Windows-based client/server application with database functionality for managing and storing flight record information. The CAFRS software can be installed on any Windows-based platform. CAFRS supports battalion- and company-level operations during deployed operations, to include split-base operations and in garrison.

Figure 1 shows the high-level concept of operations of CAFRS v4.0 with both the Army's Forces Command (FORSCOM) and Training and Doctrine Command (TRADOC) architectures. 


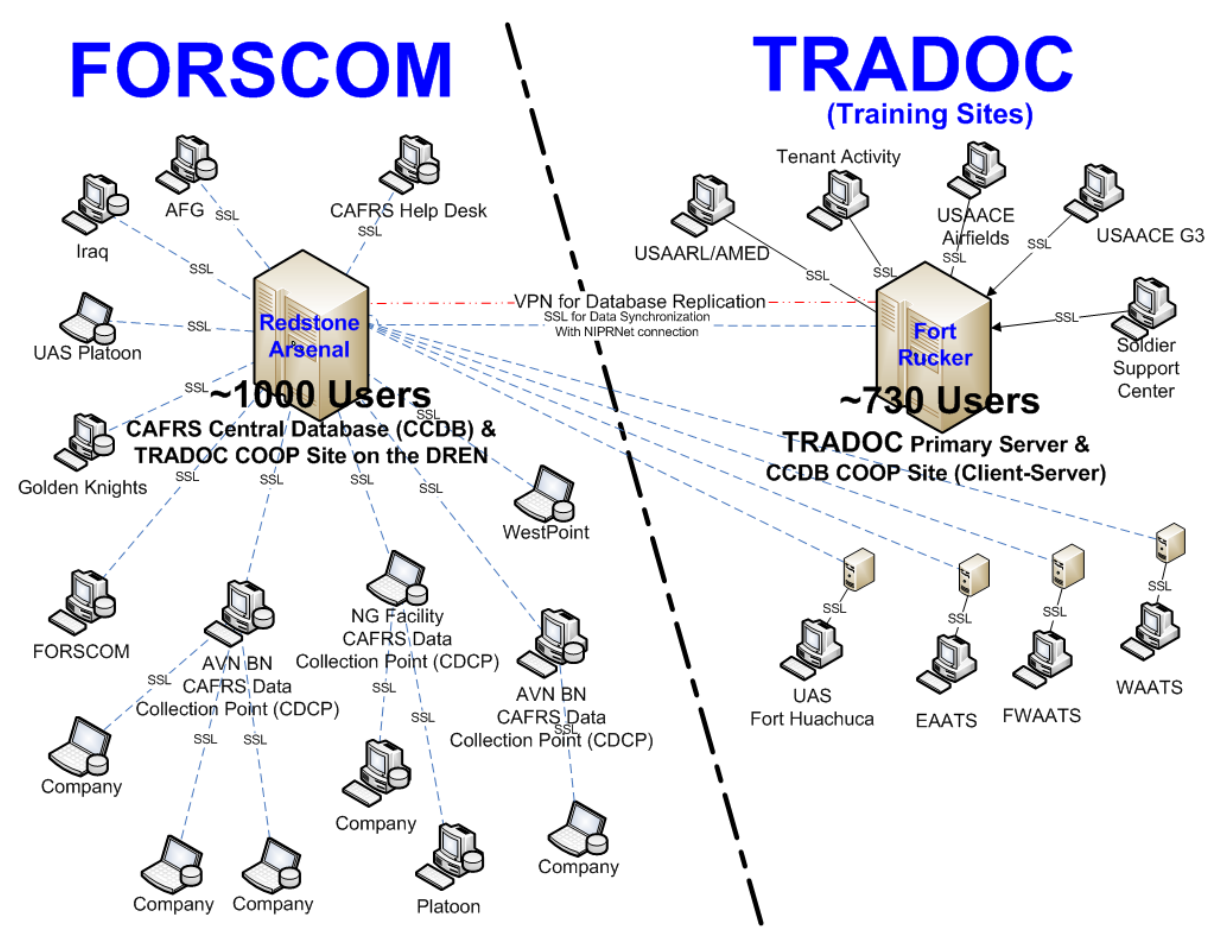

Fig. 1 CAFRS architecture

The CAFRS FORSCOM architecture (Fig. 2) has a local database installed on each CAFRS FORSCOM client machine where all data transactions occur. Network connectivity from a CAFRS FORSCOM client to the central database at Redstone Arsenal, AL, or network connectivity from a company-level CAFRS FORSCOM client to a battalion-level CAFRS FORSCOM machine is not required to perform daily operations. A battalion-level CAFRS machine setup to allow company-level machines to connect for data synchronization is known as a CAFRS Data Collection Point (CDCP). 


\section{CAFRS FORSCOM Local DB Architecture}

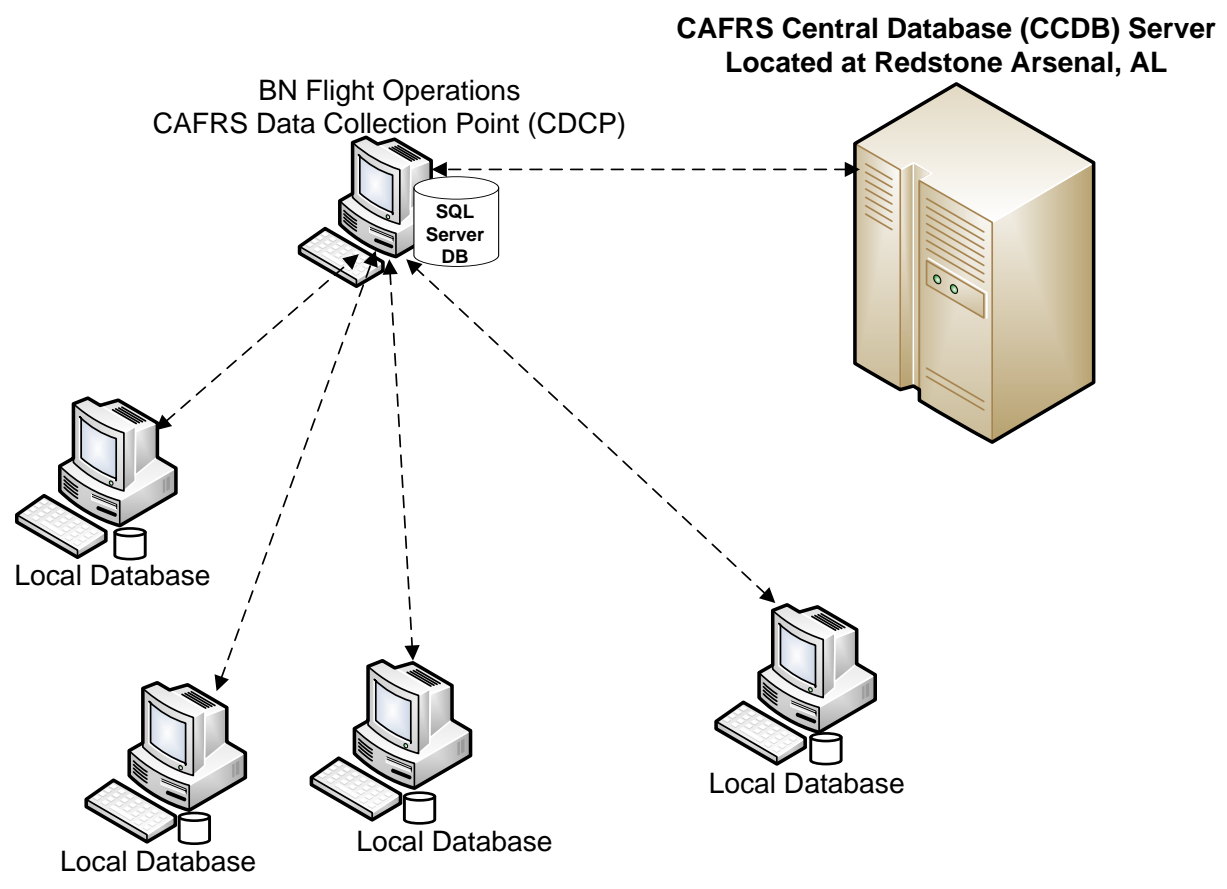

Fig. 2 CAFRS FORSCOM local database architecture

The CAFRS TRADOC architecture shown in Fig. 3 does not have a local database installed on the CAFRS TRADOC client machines. Network connectivity is required for daily operations. All CAFRS TRADOC client machines connect to the TRADOC CAFRS Central Database (CCDB) server where all the data transactions occur. 


\section{CAFRS TRADOC Architecture}

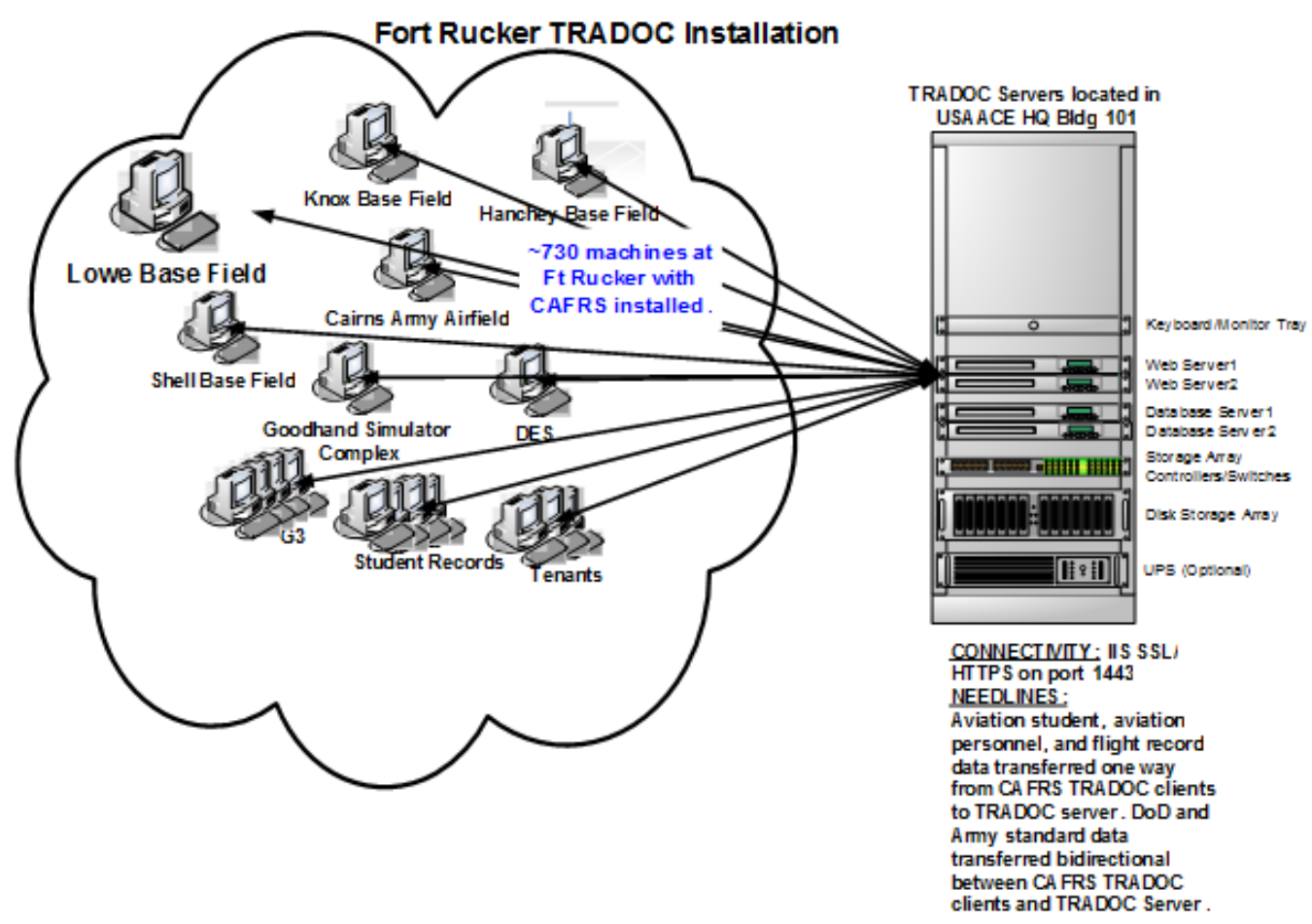

Fig. 3 TRADOC connectivity architecture

The architecture and data flow of CAFRS v4.0 (Fig. 4) consists of the following 3 tiers and nodes:

- CAFRS enterprise servers are the first and highest tier or node in the CAFRS architecture. There are 2 types of enterprise-level servers supporting CAFRS: the CCDB enterprise server or primary CCDB, and the TRADOC CCDB enterprise server or secondary CCDB.

- CDCPs make up the second tier or node of the CAFRS architecture. Numerous CDCPs exist at the Army aviation battalion-level and equivalent organizations, such as Army Aviation Support Facilities within the Army National Guard (ARNG), Operational Support Airlift Command fixed-wing flight detachments, and UAS platoons. The CDCPs' primary functions are to operate as CAFRS clients to support management of aviation flight and training records and to perform data synchronization with the CCDB to keep data current within the CCDB and within each of the CDCPs.

- CAFRS client machines make up the third and lowest tier or node of the CAFRS architecture. A CAFRS client machine is defined as any government computer that has the CAFRS client application installed. Numerous CAFRS client machines operate at all levels to include, but are not limited to, platoon, company, battalion, and other equivalent type organizations, i.e., basically at any level where Army aviation personnel and their flight record data need to be managed. 


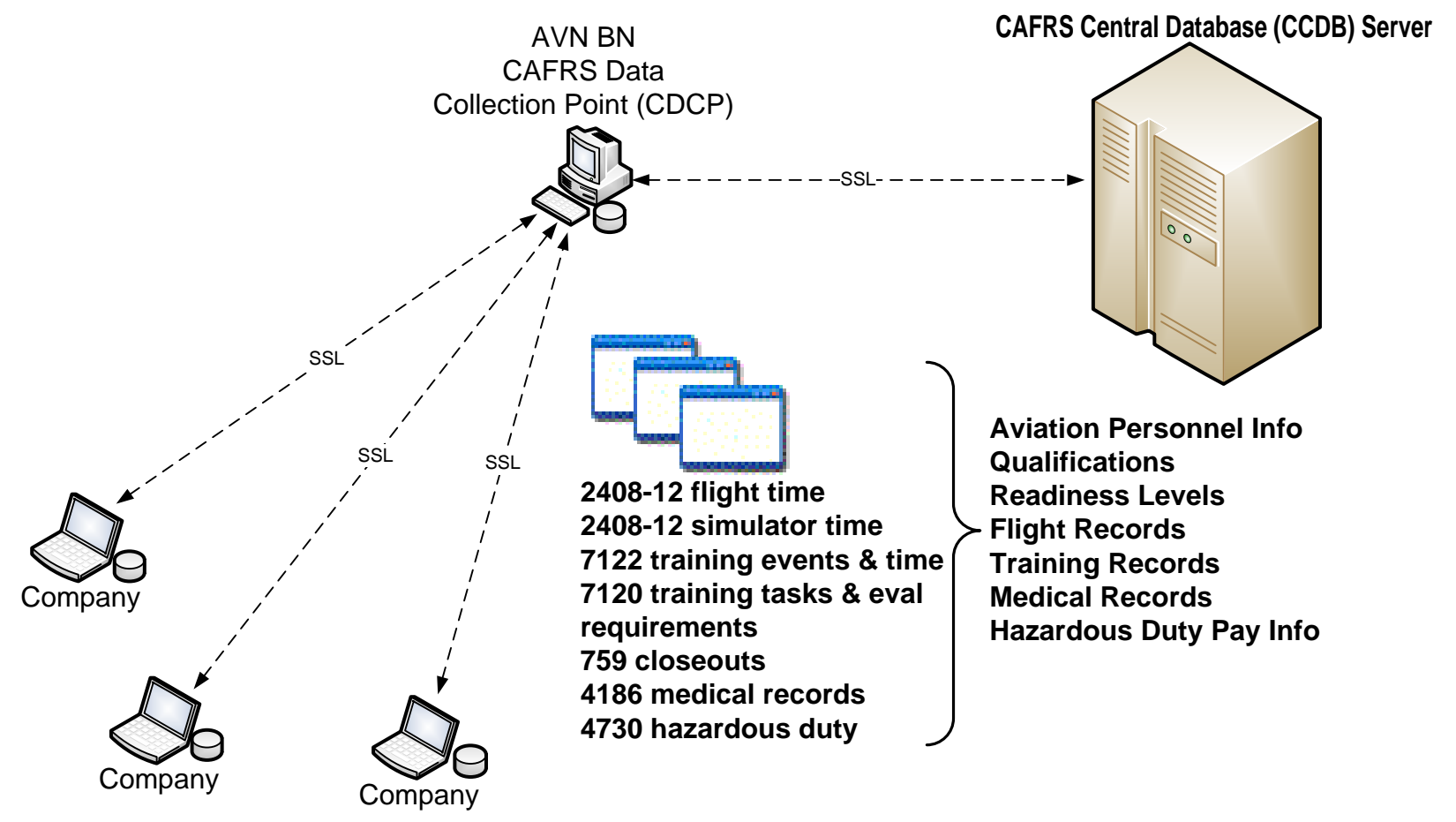

Fig. 4 CAFRS v4.0 data flow

A CAFRS person consists of 2 categories, the user and the aviation person. A CAFRS user is one who has been set up in CAFRS with a login and password for data access. They have no records. An aviation person may be a rated crew member, a nonrated crew member, or a UAS operator, and will have an individual flight record folder associated with them. A user may also belong to ATC, as in the case of a flight operations officer in charge.

A CAFRS user requires permissions to perform virtually any function within CAFRS, such as reviewing the commander's task list (CTL) (Fig. 5), accessing a Department of the Army (DA) 7120 progress report (Fig. 6), adding a custom event (Fig. 7), or accessing and updating a DA 7122 crew member's training record (Fig. 8). The CTL is a list of military tasks meant to be used as a tool to accomplish the commander's intent. The DA 7120 progress report allows a crew member to track the progress of the required task, and the DA 7122 is a comprehensive record of the crew member's training. These permissions will typically be granted by a CAFRS unit administrator based on the role of the user needing the permission. Within CAFRS, some permissions are grouped into common roles based on job description. This allows, for example, a safety officer to have a set of permissions based on his role of safety. These roles can be tailored to meet the needs of each unit. 


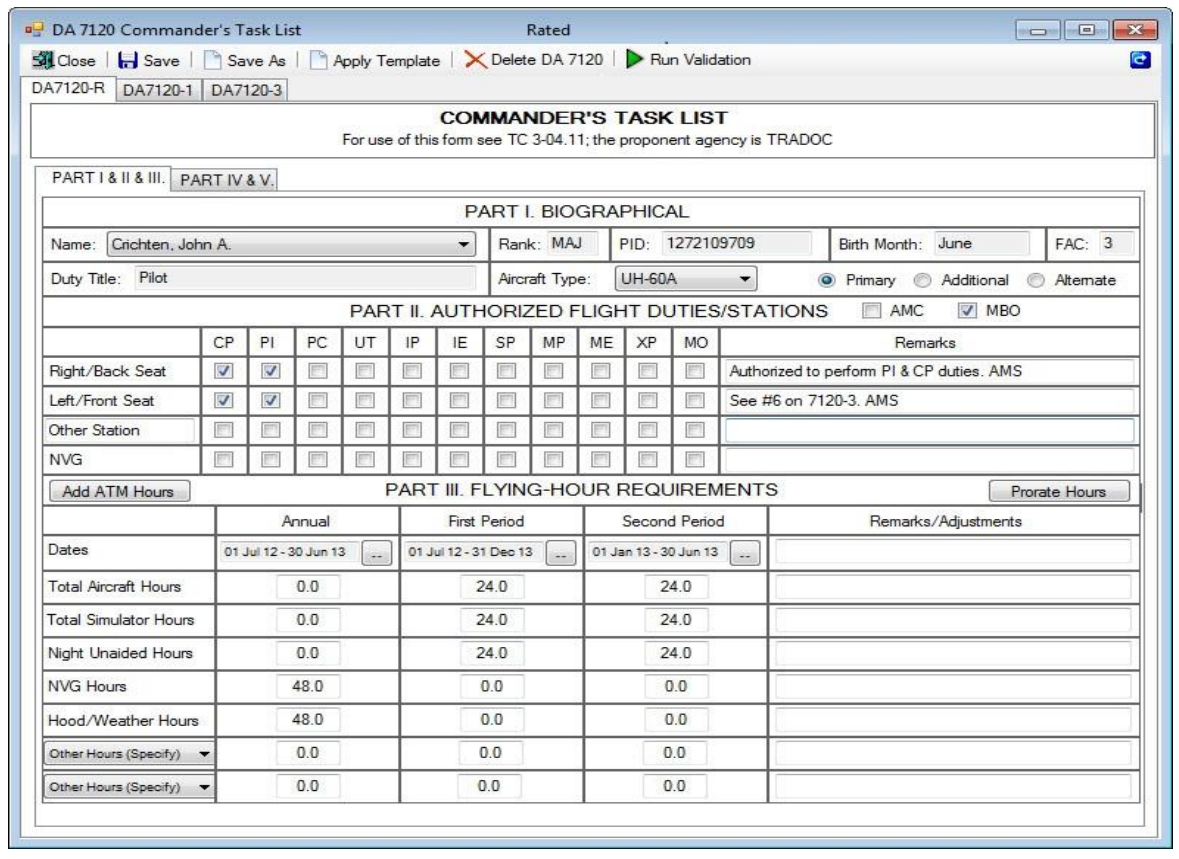

Fig. 5 Commander's task list

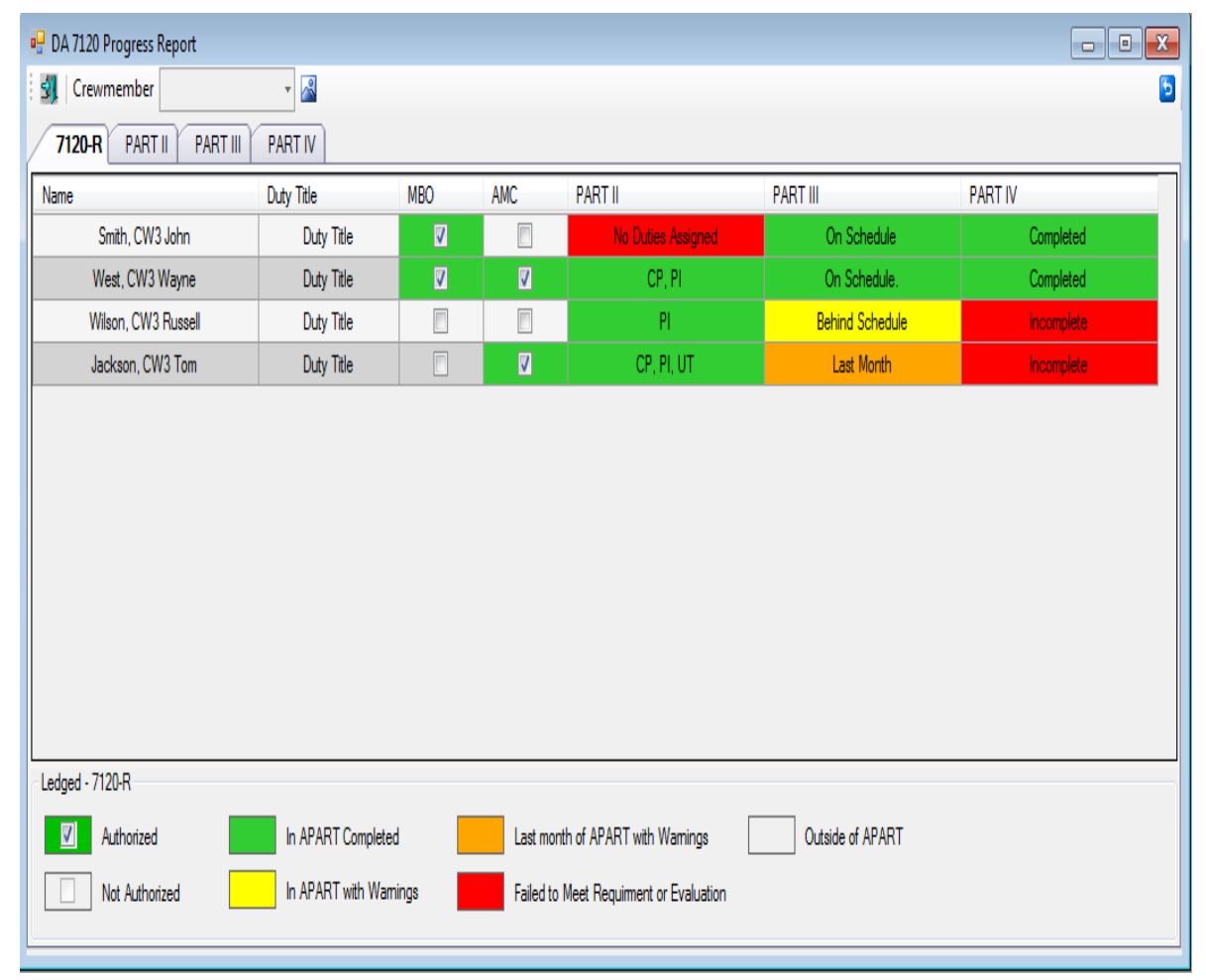

Fig. 6 DA 7120 progress report 


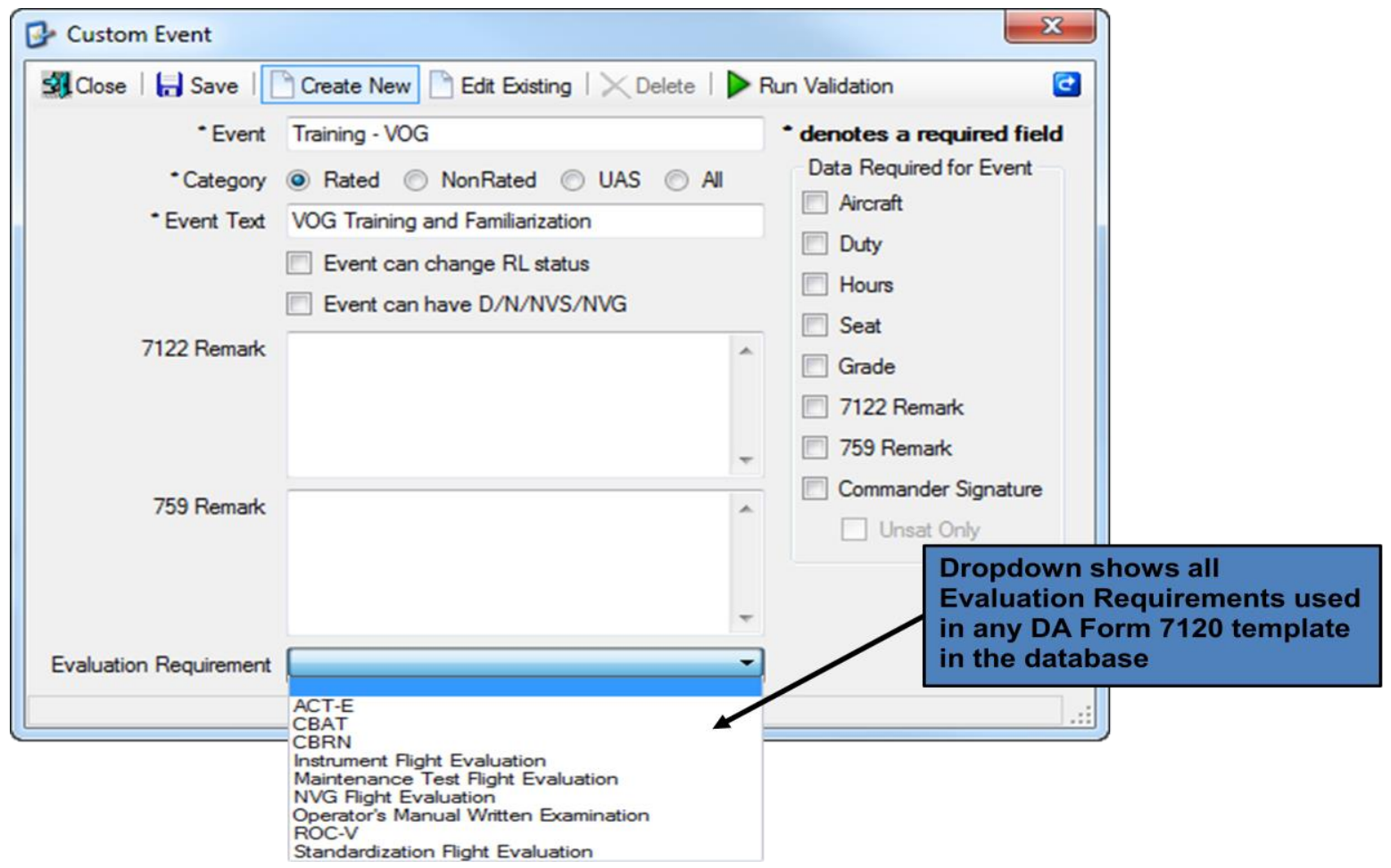

Fig. 7 Custom event screen

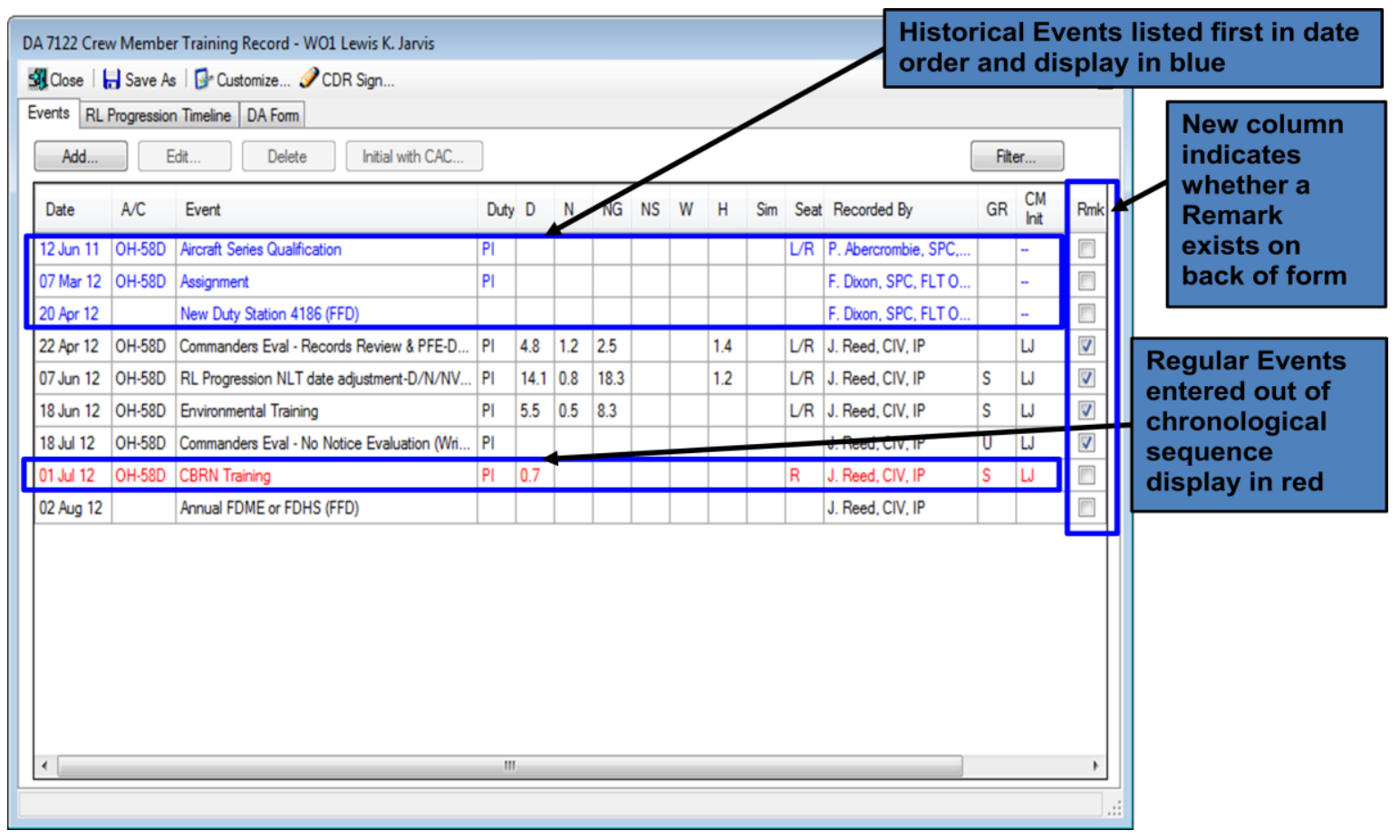

Fig. 8 DA 7122 crew member training record 


\section{Method}

Test participants received $2-3 \mathrm{~h}$ of training prior to the beginning of each UTE. The training consisted of classroom instruction and hands-on training using a Toughbook personal computer loaded with the CAFRS v4.0 software.

\subsection{Test Participants}

At total of 14 CAFRS users participated in UTE 1 (6 users) and UTE 2 (8 users). The relevant demographic characteristics of the users are listed in the Results section of this report.

\subsection{Data Collection}

A software interface questionnaire was used to assess the v4.0 design characteristics that enhanced or degraded user performance. The questionnaire was developed in accordance with published guidelines for proper format and content (O'Brien and Charlton 1996). A pretest was conducted to refine the questionnaire and to ensure that it could be easily understood and completed by test participants.

At the completion of each UTE, the users completed the software interface assessment questionnaire. Questionnaire results were clarified with information obtained during discussions with the users and during the after-action review that was conducted at the end of each UTE.

Test participants also recorded the time required to complete each task and whether they successfully completed the tasks. Problems with the software interface and system functionality were identified and recorded during the UTEs. This helped ensure that the problems would be tracked and resolved for future CAFRS upgrades.

\subsection{Assessment Limitations}

Primary limitations included the small sample size of users $(\underline{N}=14)$ who participated in UTE 1 and UTE 2 and limited test time.

These limitations are fairly common due to funding and time constraints. However, the information and data listed in the Results and Conclusions sections of this report should be interpreted based on these limitations. Additional data should be collected during future user and operational tests to augment and expand the findings contained in this report.

\section{Results}

The following is a summary of the data collected during UTE 1 and UTE 2. 


\subsection{Participant Demographic Data}

The participants $(\underline{\mathrm{N}}=14)$ were warrant officers, noncommissioned officers (NCOs), and DA civilians. Two participants held the rank of chief warrant (CW) 5, 4 held the rank of CW4, 3 held the rank of sergeant first class (SFC), one held the rank of staff sergeant (SSG), one held the rank of sergeant (SGT), and 3 were DA civilians. The participants represented a fairly broad range of experience with CAFRS and previous versions of flight records management systems.

Job Title (UTE 1):

- Flight records branch chief

- Battalion standardization pilot

- Standardization pilot

- Brigade standardization pilot

- UAS standardization instructor operator

- UH-60 repairer, nonrated crew member flight instructor

Job Title (UTE 2):

- Brigade standardization pilot

- Regiment standardization pilot

- ARNG standardization officer

- AH-64 Apache helicopter repairer/test and evaluation NCO

- UH-60 helicopter repairer

- $15 \mathrm{~W}$ senior small group leader

- Helicopter instructor pilot

- Flight records branch chief

Test participant experience with the following systems:

\section{ACFRS}

(UTE 1)

Average $=0.3$ years

Range $=0-2$ years

(UTE 2)

Average $=2.9$ years

Range $=0-5$ years 
CAFRS

(UTE 1)

Average $=2.5$ years

Range $=0-5.3$ years

(UTE 2)

Average $=3$ years

Range $=0-3$ years

ULLS-A

(UTE 1)

Average $=4.2$ years

Range $=0-16$ years

(UTE 2)

Average $=3.4$ years

Range $=0-8$ years

Computer skill level ratings (e.g., proficiency, experience, and comfort):

Mean rating for UTE 1 computer skill level was 1.8.

\begin{tabular}{c|c|cc}
\cline { 2 - 3 } 1 & 1.8 & 2 & 3 \\
\hline $\begin{array}{c}\text { High Skill } \\
\text { Level }\end{array}$ & $\begin{array}{c}\text { Moderate Skill } \\
\text { Level }\end{array}$ & $\begin{array}{c}\text { Low Skill } \\
\text { Level }\end{array}$
\end{tabular}

Mean rating for UTE 2 computer skill level was 2.25.

\begin{tabular}{cccc}
1 & 2 & 2.2 & 3 \\
\hline $\begin{array}{c}\text { High Skill } \\
\text { Level }\end{array}$ & $\begin{array}{c}\text { Moderate Skill } \\
\text { Level }\end{array}$ & $\begin{array}{c}\text { Low Skill } \\
\text { Level }\end{array}$
\end{tabular}

\subsection{CAFRS Software User Interface Assessment}

The CAFRS software user interface questionnaire was the primary data collection tool used in this assessment. Soldiers were asked specific questions about how logical and consistent a task was to complete, the number of steps involved in completing a task, and how quickly they were able to perform a task. Soldiers were also asked to rate the CAFRS software based on a number of variables including how easy it was to navigate, the speed at which the software performed tasks, and effectiveness of the Help menu. Table 1 is a summary of the test participant responses to the questionnaire. 
Table 1 CAFRS software user interface assessment results

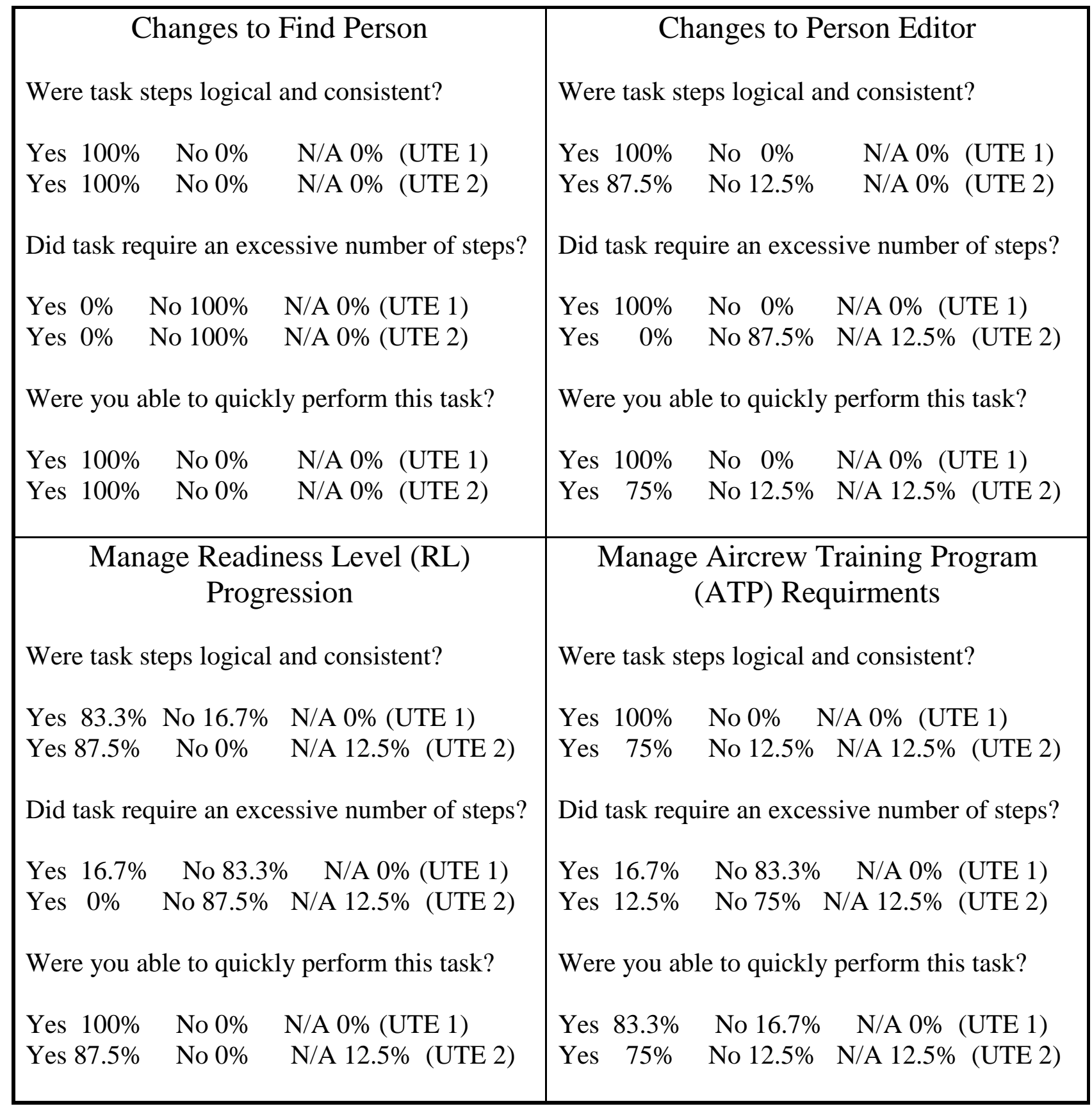


Table 1 CAFRS software user interface assessment results (continued)

\begin{tabular}{|c|c|}
\hline Manage Crewmenber Training Record & Manage Waivers and Extensions \\
\hline Were task steps logical and consistent? & Were task steps logical and consistent? \\
\hline Yes $100 \% \quad$ No $0 \% \quad$ N/A $0 \%$ (UTE 1 ) & Yes $100 \%$ No $0 \% \quad$ N/A $0 \%$ (UTE 1 ) \\
\hline Yes $87.5 \% \quad$ No $0 \% \quad$ N/A $12.5 \%$ (UTE 2) & Yes $87.5 \% \quad$ No $0 \% \quad$ N/A $12.5 \%$ (UTE 2) \\
\hline Did task require an excessive number of steps? & Did task require an excessive number of steps? \\
\hline Yes $33.3 \%$ No $66.7 \%$ N/A $0 \%$ (UTE 1 ) & N/A $0 \%$ (UTE 1) \\
\hline Yes $\quad 0 \% \quad$ No $87.5 \%$ N/A $12.5 \%$ (UTE 2) & Yes $0 \% \quad$ No $87.5 \% \quad$ N/A $12.5 \%$ (UTE 2) \\
\hline Were you able to quickly perform this task? & Were you able to quickly perform this task? \\
\hline Yes $66.7 \%$ No $33.3 \%$ & N/A $0 \%$ (UTE 1) \\
\hline Yes $75 \%$ No $12.5 \%$ N/A $12.5 \%$ (UTE 2) & N/A $12.5 \%$ (UTE 2) \\
\hline Manage Commanders's Task List & Changes to Record Status Report \\
\hline Were task steps logical and consistent? & Were task steps logical and consistent? \\
\hline N/A $0 \%$ (UTE 1) & N/A $66.7 \%$ (UTE 1) \\
\hline Yes $87.5 \% \quad$ No $0 \% \quad$ N/A $12.5 \%$ (UTE 2) & N/A $12.5 \%$ (UTE 2) \\
\hline Did task require an excessive number of steps? & Did task require an excessive number of steps? \\
\hline N/A $0 \%$ (UTE 1) & N/A $50 \%$ (UTE 1) \\
\hline Yes $12.5 \%$ No $75 \%$ N/A $12.5 \%$ (UTE 2) & N/A $12.5 \%$ (UTE 2) \\
\hline Were you able to quickly perform this task? & Were you able to quickly perform this task? \\
\hline Yes $83.3 \%$ No $16.7 \%$ N/A $0 \%$ (UTE 1 ) & N/A $50 \%$ (UTE 1) \\
\hline Yes $75 \%$ No $12.5 \%$ N/A $12.5 \%$ (UTE 2) & N/A $12.5 \%$ (UTE 2) \\
\hline
\end{tabular}

UTE 1 participant comments:

- Standard remarks for 7122s were not arranged in an order that was logical to me. Numerous steps in creating CTL templates; many tasks I was not familiar with due to not having experience managing individual aviation training folders (IATFs).

- Most windows required scrolling.

- CTL template: Name should be at top. I had to scroll to find it.

- Had some difficulty selecting aircraft for the CM to progress. 
- For a new user of this program, the steps and navigation for the crew member training record were somewhat overwhelming.

- Manage readiness level (RL) Progression: Should operate through 7122 entry.

UTE 2 comments:

- 7120 -1: Task iteration is too complicated.

- Crew member task list date entry was a little tricky. Entering the date would not allow the day to be entered until you first adjusted the year. The date entry went from right to left instead of how one normally reads (left to right).

Table 2 CAFRS software user interface assessment results

2. Did you experience any problems with the following user-interface characteristics of CAFRS 4.0?

Was the wording (terms, abbreviations, etc) presented on the screens simple and easy to understand?

$$
\begin{array}{llll}
\text { Yes } 100 \% & \text { No } 0 \% & \text { (UTE 1) } \\
\text { Yes } 100 \% & \text { No } 0 \% & \text { (UTE 2) }
\end{array}
$$

Were there any tabs or buttons that were not logically named?

$$
\begin{array}{rrrr}
\text { Yes } & 16.7 \% & \text { No } & 83.3 \% \\
\text { Yes } & 0 \% & \text { No } & 100 \% \\
\text { (UTE 1) }
\end{array}
$$

Was the information presented on the menu screens efficiently arranged so you did not have to spend a lot of time searching for it?

$$
\begin{aligned}
& \text { Yes } 66.7 \% \text { No } 33.3 \% \text { (UTE 1) } \\
& \text { Yes } 100 \% \text { No 0\% (UTE 2) }
\end{aligned}
$$

Was the order in which you were required to enter data on the menu screens intuitive and logical?

$$
\begin{aligned}
& \text { Yes } 66.7 \% \text { No } 16.7 \% \text { N/A 16.7\% (UTE 1) } \\
& \text { Yes } 100 \% \text { No } 0 \% \text { (UTE 2) }
\end{aligned}
$$

Could you easily reverse an input you made in CAFRS 4.0 (e.g., delete an entry) when you made an error?

$$
\begin{array}{ll}
\text { Yes } 50 \% & \text { No 50\% (UTE 1) } \\
\text { Yes } 87.5 \% & \text { No 12.5\% (UTE 2) }
\end{array}
$$

Did error messages provide enough information to understand the problem?

$$
\begin{array}{lll}
\text { Yes } 100 \% & \text { No 0\% } & \text { (UTE 1) } \\
\text { Yes } 100 \% & \text { No 0\% } & \text { (UTE 2) }
\end{array}
$$


UTE 1 participant comments:

- CTL template: Only backspace could be used to delete number of iterations.

- $\quad$ Use to Person Editor in 3.0.3.

- Once you enter a comment on the 7120 and save it, you can't go back and modify or remove it.

- Trying to organize an out of date entry before the CM initials. Any changes or edits to the events will set it out of order and to the bottom of the page.

- Entering a 7122 event was not consistent with a paper 7122.

UTE 2 comments:

- Still needs permissions to work.

- Event entries regarding changes from one RL status to another status is confusing. I talked to Paul Williams about changing event entries to simplify. Ex: "Compl RL3 ref tng Designated RL2 D/N, RL3 Night Vision Goggles (NVG)".

- Once entry is made on 7122 initial and signed and remark PART759 annotated and the entry was made by mistake, those remarks cannot be deleted on the 759 .

3. Overall, how quickly were you able to navigate through the CAFRS 4.0 screens to perform tasks? (Circle one.)

Mean UTE 1 rating was 2.2.

\begin{tabular}{cc|cccc}
\cline { 5 - 6 } 1 & 2 & 2.2 & 3 & 4 & 5 \\
\hline $\begin{array}{c}\text { Very } \\
\text { Quickly }\end{array}$ & $\begin{array}{c}\text { Somewhat } \\
\text { Quickly }\end{array}$ & Borderline & $\begin{array}{c}\text { Somewhat } \\
\text { Slowly }\end{array}$ & $\begin{array}{c}\text { Very } \\
\text { Slowly }\end{array}$
\end{tabular}

Mean UTE 2 rating was 1.8 .

\begin{tabular}{|c|c|c|c|c|c|}
\hline 1 & 1.8 & 2 & 3 & 4 & 5 \\
\hline $\begin{array}{c}\text { Very } \\
\text { Quickly }\end{array}$ & $\begin{array}{l}\text { Son } \\
\text { Qu }\end{array}$ & $\begin{array}{l}\text { newhat } \\
\text { aickly }\end{array}$ & Borderline & $\begin{array}{l}\text { Somewhat } \\
\text { Slowly }\end{array}$ & $\begin{array}{l}\text { Very } \\
\text { Slowly }\end{array}$ \\
\hline
\end{tabular}


4. Rate the effectiveness of the CAFRS 4.0 "Help" for troubleshooting problems. (Circle one.) Mean UTE 1 rating was 1.8.

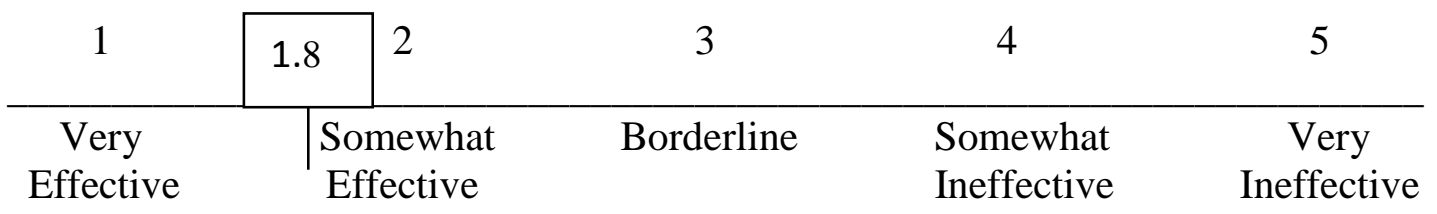

Mean UTE 2 rating was 2.0.

\begin{tabular}{ccccc}
\cline { 2 - 5 } 1 & 2.0 & 3 & 4 & 5 \\
\hline $\begin{array}{c}\text { Very } \\
\text { Effective }\end{array}$ & $\begin{array}{c}\text { Sompwhat } \\
\text { Effective }\end{array}$ & Borderline & $\begin{array}{c}\text { Somewhat } \\
\text { Ineffective }\end{array}$ & $\begin{array}{c}\text { Very } \\
\text { Ineffective }\end{array}$
\end{tabular}

5. Rate how quickly (or slowly) CAFRS 4.0 operated on the computer. (Circle one)

Mean UTE 1 rating was 2.7.

\begin{tabular}{cll|llc}
\cline { 3 - 5 } 1 & 2 & 2.7 & 3 & 4 & 5 \\
\hline $\begin{array}{c}\text { Very } \\
\text { Quickly }\end{array}$ & $\begin{array}{c}\text { Somewhat } \\
\text { Quickly }\end{array}$ & & Borderline & $\begin{array}{c}\text { Somewhat } \\
\text { Slowly }\end{array}$ & $\begin{array}{c}\text { Very } \\
\text { Slowly }\end{array}$
\end{tabular}

Mean UTE 2 rating was 1.8 .

\begin{tabular}{|c|c|c|c|c|c|}
\hline 1 & 1.8 & 2 & 3 & 4 & 5 \\
\hline $\begin{array}{c}\text { Very } \\
\text { Ouickly }\end{array}$ & $\begin{array}{l}\text { So } \\
\text { O }\end{array}$ & $\begin{array}{l}\text { mewhat } \\
\text { lickly }\end{array}$ & Borderline & $\begin{array}{l}\text { Somewhat } \\
\text { Slowly }\end{array}$ & $\begin{array}{c}\text { Very } \\
\text { Slowly }\end{array}$ \\
\hline
\end{tabular}

If you rated the operating speed as "Somewhat Slowly" or "Very Slowly", describe how this affected your performance:

UTE 1 participant comments:

- Waiting for pages to load.

- I think it was mostly due to an older computer. 
UTE 2 participant comments:

- Speed was attributed to processing power of computer.

6. Overall, were you faster or slower when using CAFRS v4.0 versus using CAFRS v3.0.3? (Circle one)

Mean UTE 1 rating was 3.4.

\begin{tabular}{|c|c|c|c|c|c|}
\hline 1 & 2 & 3 & 3.4 & 4 & 5 \\
\hline Much Faster & Somewhat Faster & About & & Somewhat Slower & Much Slo \\
\hline
\end{tabular}

Mean rating was 2.7 (UTE 2).

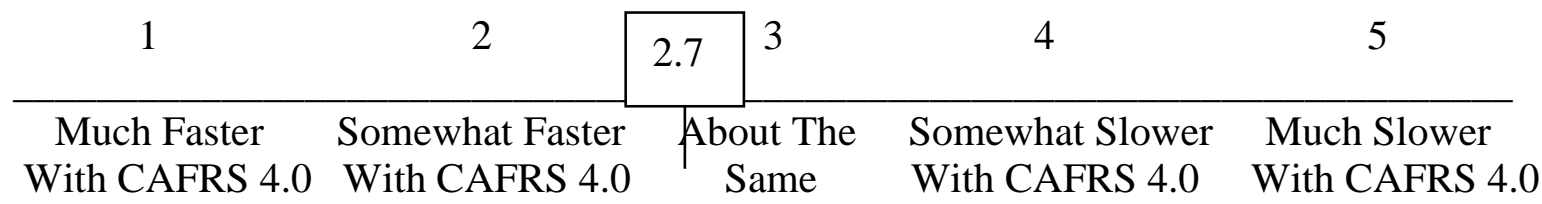

If you were "Somewhat Slower" or "Much Slower" with CAFRS v4.0, explain why:

UTE 1 participant comments:

- Person Editor screen was totally rearranged and looks nothing like version 3.0.3.

UTE 2 participant comments:

- Person editor has been changed completely and also tool bars have been changed.

- First time using CAFRS, software was intuitive.

Describe any other positive or negative characteristics of CAFRS v4.0 that impacted your performance:

UTE 1 participant comments:

- Not having ability to change Part III on Person Editor could affect number of "errors" on closeout.

- Need UAS aircrew training manual tasks

UTE 2 participant comments:

- Would like to see more validation on 7122 . 
- CAFRS was very user friendly and will enhance our IATF capability in my unit.

- Fairly user friendly considering I have no experience with CAFRS.

- The system is very user friendly and easy to navigate. I am very limited in my experience. What I did notice was the lack of 2397-U form. Did not affect my performance, but it is a necessary form for incidents in the UAS community.

- Blocking Part III and aircraft qualification dates from being modified through Person Editor causes numerous errors on the 759.

During the UTEs, test participants completed a series of tasks and subtasks. For each task and subtask the evaluation software recorded the steps taken by the test participant and compared that with the appropriate preloaded steps. All steps taken in appropriate sequence to complete that specific task were recorded as a pass. Each occurrence of a diversion from the appropriate steps was recorded as a fail. The time required to complete the task was documented by the test participants. Table 3 shows each task, the number of passes and fails, and the average time (in minutes) it took to accomplish each task.

UTE 1 test participants had an $80 \%$ pass rate and took an average of 34 min to complete tasks (Table 3). UTE 2 test participants had a 94\% pass rate and took an average of $32 \mathrm{~min}$ to complete tasks (Table 4). There was variability between test participants in how long it took them to complete the tasks. The variability was mostly because of the different levels of experience and proficiency with CAFRS among participants. The tasks that were performed during UTE 1 and UTE 2 were not identical. However, some of the increase in task pass rates and slight reduction in task times for UTE 2 can be attributed to software improvements that were made after UTE 1. 
Table 3 UTE 1 task pass/fail and completion times

\begin{tabular}{|c|c|c|c|c|}
\hline Task & Pass & Fail & $\begin{array}{c}\text { Avg. Time } \\
\text { (min) }\end{array}$ & $\begin{array}{l}\text { Standard } \\
\text { Deviation } \\
\end{array}$ \\
\hline Getting started: register common access card (CAC) & 5 & 0 & 7 & 5 \\
\hline Getting started: set up and manage working sets & 7 & 0 & 15 & 11 \\
\hline Getting started: find person & 7 & 0 & 11 & 8 \\
\hline 01 Create IATF for aviator & 5 & 10 & 187 & 64 \\
\hline 02 Create IATF for self & 8 & 0 & 111 & 92 \\
\hline 03 Create CTL template & 7 & 2 & 28 & 18 \\
\hline 01A Create DA7122 event & 8 & 0 & 51 & 47 \\
\hline 01B.1 Create DA 7120 & 3 & 4 & 33 & 15 \\
\hline 01B. 2 Create DA 7120 & 4 & 1 & 47 & 35 \\
\hline 01B.3 Create DA 7120 & 1 & 1 & 9 & 5 \\
\hline 01B.4 Create DA 7120 & 2 & 0 & 7 & 4 \\
\hline 01C RL progression & 2 & 0 & 9 & 6 \\
\hline 01D Create and apply a unit wavier & 3 & 0 & 5 & 0 \\
\hline 01E Create and apply an individual waiver & 3 & 0 & 4 & 1 \\
\hline 01F Create and apply a unit extension & 3 & 0 & 12 & 7 \\
\hline 01G Create and apply an individual extension & 3 & 0 & 8 & 4 \\
\hline TOTALS & 71 & 18 & 34 & \\
\hline
\end{tabular}

Pass/failure percentage for tasks

$80 \% \quad 20 \%$ 
Table 4 UTE 2 task pass/fail and completion times

\begin{tabular}{|c|c|c|c|c|}
\hline Task & Pass & Fail & $\begin{array}{c}\text { Avg. Time } \\
\text { (min) }\end{array}$ & $\begin{array}{l}\text { Standard } \\
\text { Deviation }\end{array}$ \\
\hline Getting started: register CAC & 8 & 0 & $\ldots$ & $\ldots$ \\
\hline Getting started: set up and manage working sets & 19 & 0 & $\ldots$ & $\ldots$ \\
\hline Getting started: find person & 17 & 0 & $\ldots$ & $\ldots$ \\
\hline 01A Create DA7122 event & 25 & 0 & 94 & 41 \\
\hline 01B.1_Create a DA 7120-R basic & 25 & 5 & 50 & 43 \\
\hline 01B.2_Create a DA 7120-R template & 34 & 3 & 30 & 17 \\
\hline 01B.3 Create DA 7120-1 & 18 & 1 & 19 & 13 \\
\hline 01B.4 Create DA 7120-3 & 21 & 8 & 16 & 8 \\
\hline 01C RL progression and timeline & 27 & 0 & 40 & 24 \\
\hline 02A Create and apply a unit waiver & 21 & 0 & 18 & 9 \\
\hline 02B Create and apply an individual waiver & 7 & 1 & 22 & 10 \\
\hline 02C Create and apply a unit extension & 34 & 0 & 20 & 20 \\
\hline 02D Create and apply an individual extension & 26 & 3 & 29 & 23 \\
\hline 03_Create a CTL Template & 27 & 1 & 34 & 11 \\
\hline 04_Search_IATF & 16 & 0 & 7 & 4 \\
\hline 05_Ad Hoc & 8 & 0 & 8 & 3 \\
\hline TOTALS & 333 & 22 & 32 & \\
\hline
\end{tabular}

Pass/failure percentage for tasks

$94 \% \quad 6 \%$


If test participants encountered problems with the software, an issue trouble report was created. The list of UTE 1 issues is in the Appendix. Several of the issues were addressed and resolved between UTE 1 and UTE 2 to improve the user interface and software functionality.

\section{Conclusions}

\subsection{CAFRS v4.0 Software Interface}

The participants reported they were able to effectively use the CAFRS v4.0 software during UTE 1 and UTE 2. They indicated that they were able to quickly complete most tasks, navigate through the menu screens fairly quickly, task steps were logical and consistent, wording on the menu screens was easy to understand, error messages were understandable, and they were able to complete tasks about as quickly with $\mathrm{v} 4.0$ as with v3.0.3. They identified usability issues with some of the design characteristics of v4.0 (e.g., data entry for 7122 tasks). All participants reported that they experienced problems when using Person Editor during UTE 1. None of the participants reported problems using the Person Editor during UTE 2. Fifty percent of participants reported that it was easy to reverse an input when they made an error during UTE 1 . Based (partly) on the changes made after UTE 1, 87.5\% of participants reported that it was easy to reverse an input when they made an error during UTE 2.

\subsection{Task Completion Rates and Tasks Times}

Participants reported an $80 \%$ pass rate when performing tasks with the CAFRS v4.0 software during UTE 1. Data collected during UTE 1 resulted in improvements to the CAFRS v4.0 software based on user input during the assessment. Based (partly) on the improvements made after UTE 1, users reported a 94\% pass rate when performing tasks during UTE 2. Overall task time completion was $34 \mathrm{~min}$ for UTE 1 and $32 \mathrm{~min}$ for UTE 2. There were some differences in the tasks performed during UTE 1 versus UTE 2.

In summary, the participants were able to effectively maintain aviation flight records and quickly complete most tasks during UTE 1 and UTE 2. Software interface and functionality issues were reported by the participants and addressed by the software developers during (and after) UTE 1 and are being addressed after UTE 2 . Work should continue to address the issues until they are resolved. Future software releases should be assessed to ensure that an intuitive software interface is provided to allow users to perform flight records management tasks quickly and accurately. Consideration should be given to developing a mobile web-based version of CAFRS (that synchronizes with ULLS-A) to expedite data entry and reduce manpower requirements for records management. 


\section{References}

O'Brien TG, Charlton SG. The role of human factors testing and evaluation in system development. In: Handbook of human factors testing and evaluation. Mahwah (NJ): Lawrence Erlbaum and Associates; 1996. 
Appendix. CAFRS v4.0 UTE 1 Trouble Reports

This appendix appears in its original form, without editorial change. 


\begin{tabular}{|c|c|c|c|}
\hline Number & $\begin{array}{l}\text { Rec. } \\
\text { Priority }\end{array}$ & Summary & Status \\
\hline 9720 & 2 & $\begin{array}{l}\text { V4.0 UTE 1: (TR 54) - RL Progression -- Select N/A for NVG get } \\
\text { error, but if you leave it blank no error. }\end{array}$ & $\begin{array}{l}\text { Closed (Cannot } \\
\text { Reproduce) }\end{array}$ \\
\hline 9711 & -1 & v4.0 UTE 1: (TR 16) - 7122 Clear Out of Sequence entries & $\begin{array}{l}\text { Closed } \\
\text { (Duplicate) }\end{array}$ \\
\hline 9729 & 4 & $\begin{array}{l}\text { v4.0 UTE 1: (TR34): CTL Template: Enter Eval iterations not } \\
\text { intuiative. }\end{array}$ & $\begin{array}{l}\text { Closed } \\
\text { (Duplicate) }\end{array}$ \\
\hline 9730 & 4 & $\begin{array}{l}\text { V4.0 UTE 1: (TR 18) - W\&E: Redundant (Hours) in comment } \\
\text { instead of entering actual hours not useful. }\end{array}$ & $\begin{array}{l}\text { Closed } \\
\text { (Duplicate) }\end{array}$ \\
\hline 9753 & 5 & $\begin{array}{l}\text { V4.0 UTE 1: (TR 13) - DA 7120-R: After entering a } 12 \text { month } \\
\text { annual and first and second period date ranges and hours, } \\
\text { prorate of first and second period hours are prorated with no } \\
\text { logic }\end{array}$ & $\begin{array}{l}\text { Closed } \\
\text { (Duplicate) }\end{array}$ \\
\hline 9768 & 5 & $\begin{array}{l}\text { V4.0 UTE 1: (TR 31) -- DA 7120-R: Date Time picker for Part } 3 \\
\text { does not completely calculate and display from crew member's } \\
\text { ATP periods }\end{array}$ & $\begin{array}{l}\text { Closed } \\
\text { (Duplicate) }\end{array}$ \\
\hline 9772 & -1 & $\begin{array}{l}\text { V4.0 UTE 1: (TR 25) -- DA 7120-R: DA } 7120 \text { Creation Part IV } \\
\text { Commander, can there be a dropdown or right click for } \\
\text { personnel in commander roles? }\end{array}$ & $\begin{array}{l}\text { Closed } \\
\text { (Duplicate) }\end{array}$ \\
\hline 9778 & -1 & $\begin{array}{l}\text { V4.0 UTE 1: (TR 86) -- DA 7120-R: Annual and Semi-Annual } \\
\text { Periods should auto fill from birth month entry in part } 1 .\end{array}$ & $\begin{array}{l}\text { Closed } \\
\text { (Duplicate) }\end{array}$ \\
\hline 9783 & -1 & $\begin{array}{l}\text { V4.0 UTE 1: (TR 65) -- DA 7120-R: Multiple Additional Aircraft, } \\
\text { last entered is what fills in } 759 \text { Part III Block } 15 .\end{array}$ & $\begin{array}{l}\text { Closed } \\
\text { (Duplicate) }\end{array}$ \\
\hline 9784 & -1 & $\begin{array}{l}\text { V4.0 UTE 1: (TR 83) -- DA 7120-1: Editing task iterations after } \\
\text { CM and CDR sign should require re-signing (CDR initial). }\end{array}$ & $\begin{array}{l}\text { Closed } \\
\text { (Duplicate) }\end{array}$ \\
\hline 9785 & -1 & $\begin{array}{l}\text { v4.0 UTE 1: (TR 24) -- DA } 7122+7120 \text { : Cannot complete new } \\
7120 \text { for addition aircraft until CM initials the } 7122 \text { event. }\end{array}$ & $\begin{array}{l}\text { Closed } \\
\text { (Duplicate) }\end{array}$ \\
\hline 9700 & 3 & $\begin{array}{l}\text { V4.0 UTE 1: (TR01)- Nav Tree unable to redock when PC is using } \\
\text { AERO Windows Theme. }\end{array}$ & Closed (Fixed) \\
\hline 9701 & 2 & $\begin{array}{l}\text { V4.0 UTE 1: (TR07) - W\&E: Requesting NVG extension in noted } \\
\text { step causes attached error. Event guid doesn't exist. }\end{array}$ & Closed (Fixed) \\
\hline 9703 & 2 & $\begin{array}{l}\text { V4.0 UTE 1: (TR08) - Person Editor: Change CAFRS user to } \\
\text { Aviation Personnel does not create a viable record. }\end{array}$ & Closed (Fixed) \\
\hline 9707 & 4 & $\begin{array}{l}\text { v4.0 UTE 1:(TR 32) - CTL Template: } 3000 \text { Series Task creation, } \\
\text { save of task is not intuitive and no confirmation }\end{array}$ & Closed (Fixed) \\
\hline 9709 & 5 & $\begin{array}{l}\text { v4.0 UTE 1: (TR 101) - } 7122 \text { Add an event type for Non Medical } \\
\text { Suspension }\end{array}$ & Closed (Fixed) \\
\hline 9710 & 4 & v4.0 UTE 1: (TR11) - 7122 Customize button prompts to save & Closed (Fixed) \\
\hline 9714 & 4 & $\begin{array}{l}\text { V4.0 UTE 1: (TR 34) - CTL Template -- Entering Iterations with E } \\
\text { for Eval is not intuitive. }\end{array}$ & Closed (Fixed) \\
\hline 9717 & 2 & $\begin{array}{l}\text { v4.0 UTE 1: (TR44) - } 7122 \text { show complete list of ACFT series for } \\
\text { Commander's Eval - Record Review entry }\end{array}$ & Closed (Fixed) \\
\hline 9718 & 5 & $\begin{array}{l}\text { v4.0 UTE 1: (TR36) - CTL Template Export -- move export } \\
\text { button to top of window. }\end{array}$ & Closed (Fixed) \\
\hline
\end{tabular}




\begin{tabular}{|c|c|c|c|}
\hline 9719 & 5 & $\begin{array}{l}\text { V4.0 UTE 1: (TR 53) - W\&E; When entering an individual } \\
\text { extension, need to be able to enter specific details in remark. }\end{array}$ & Closed (Fixed) \\
\hline 9721 & 2 & $\begin{array}{l}\text { v4.0 UTE 1: (TR47) - } 7122 \text { CDR Signature required but not } \\
\text { allowed }\end{array}$ & Closed (Fixed) \\
\hline 9722 & 2 & $\begin{array}{l}\text { V4.0 UTE 1: (TR 99) -- DA 7120: After adding remarks to saved } \\
\text { 7120, â€ Exception During Save' error is thrown upon re- } \\
\text { saving. }\end{array}$ & Closed (Fixed) \\
\hline 9724 & 4 & $\begin{array}{l}\text { V4.0 UTE 1: (TR 37) -- DA 7120-3: Remarks on -3 are all run } \\
\text { together and unreadable on the } 7120 \text { DA FORM, need to be } \\
\text { separate lines. }\end{array}$ & Closed (Fixed) \\
\hline 9725 & 4 & $\begin{array}{l}\text { V4.0 UTE 1: (TR73) - CTL Template -- Could not delete or } \\
\text { change Iterations and numbers under } 1000 \text { series task on the } \\
\text { CTL Template. }\end{array}$ & Closed (Fixed) \\
\hline 9726 & 3 & $\begin{array}{l}\text { V4.0 UTE 1: (TR96) - W\&E - Unit Waiver at battalion level } \\
\text { doesn't include sub units. }\end{array}$ & Closed (Fixed) \\
\hline 9732 & 5 & $\begin{array}{l}\text { v4.0 UTE } 1 \text { (TR58) - Permissions: CAFRS needs the ability to } \\
\text { apply delegation authority for the ATP commander. For signing } \\
\text { the DA From } 7120 \text { and the DA From } 7122\end{array}$ & Closed (Fixed) \\
\hline 9736 & 4 & $\begin{array}{l}\text { v4.0 UTE 1: (TR 76) - DA 7120-R: Remarks disappear after } \\
\text { saved/closed and reopened on the DA FORM 7120-R. This } \\
\text { happens in Part II Authorized flight Duties. }\end{array}$ & Closed (Fixed) \\
\hline 9737 & 5 & v4.0 UTE 1: (TR Multiple) - 7122 Add event for categories & Closed (Fixed) \\
\hline 9741 & 5 & v4.0 UTE 1: (TR22) - 7122 Add simulators to Aircraft dropdown & Closed (Fixed) \\
\hline 9745 & 5 & $\begin{array}{l}\text { v4.0 UTE 1: (TR30) - } 7122 \text { Crew member can initial without } \\
\text { realizing there is a related remark on page } 2\end{array}$ & Closed (Fixed) \\
\hline 9749 & 5 & $\begin{array}{l}\text { v4.0 UTE 1: (TR 05) - DA 7120: Evals listed in the task } \\
\text { dropdown on the } 7120 \text { are not bold/caps like in the template. } \\
\text { Need them to be at least CAPS }\end{array}$ & Closed (Fixed) \\
\hline 9750 & 4 & $\begin{array}{l}\text { v4.0 UTE 1: (TR29) - } 7122 \text { Changing Event type that contains a } \\
\text { default remark prompts to change the default remark }\end{array}$ & Closed (Fixed) \\
\hline 9751 & 4 & $\begin{array}{l}\text { v4.0 UTE 1: (TR69) - } 7122 \text { Changing the Event type clears the } \\
\text { Aircraft dropdown }\end{array}$ & Closed (Fixed) \\
\hline 9756 & 5 & $\begin{array}{l}\text { v4.0 UTE 1: (TR82) - } 7122 \text { Custom Event change 'Evaluation } \\
\text { Requirement' to a dropdown selection }\end{array}$ & Closed (Fixed) \\
\hline 9757 & 5 & $\begin{array}{l}\text { v4.0 UTE 1: (TR 19) - DA 7120: Want to type in Remarks fields } \\
\text { instead of right click edit. }\end{array}$ & Closed (Fixed) \\
\hline 9758 & 5 & $\begin{array}{l}\text { v4.0 UTE 1: (TR68) - } 7122 \text { Need capability to manually enter } \\
\text { historic data }\end{array}$ & Closed (Fixed) \\
\hline 9761 & 5 & $\begin{array}{l}\text { v4.0 UTE 1: (TR 26) -- DA 7120: While creating, save } 7120 \text {, form } \\
\text { blanks. We want to review data, should not clear form. }\end{array}$ & Closed (Fixed) \\
\hline 9763 & 4 & v4.0 UTE 1: (TR63) - 7122 Extension restricts duties & Closed (Fixed) \\
\hline 9765 & 5 & v4.0 UTE 1: (TR 72) - 7122 Red Date on Printed DA Form & Closed (Fixed) \\
\hline 9767 & 4 & V4.0 UTE 1: (TR80) - 7122 Need list of uninitialed events & Closed (Fixed) \\
\hline 9771 & 4 & $\begin{array}{l}\text { v4.0 UTE 1: (TR 79) -- DA 7120: Right Click on a remark should } \\
\text { select the current row. }\end{array}$ & Closed (Fixed) \\
\hline
\end{tabular}




\begin{tabular}{|c|c|c|c|}
\hline 9775 & 5 & $\begin{array}{l}\text { v4.0 UTE 1: (TR 51) - DA 7120-R: Completion Dates for Part } 4 \text { of } \\
\text { 7120-R should be blank. }\end{array}$ & Closed (Fixed) \\
\hline 9780 & 5 & $\begin{array}{l}\text { V4.0 UTE 1: (TR 92) -- DA 7120-R: The drop down lists for PART } \\
\text { IV Other Evals and PART III Other Flying Hour requirements } \\
\text { should pull from DB not from template. }\end{array}$ & Closed (Fixed) \\
\hline 9781 & 4 & $\begin{array}{l}\text { v4.0 UTE 1: (TR 81) -- DA 7120-R: There is no indication similar } \\
\text { aircraft type information exists until you right click on the } \\
\text { aircraft field. }\end{array}$ & Closed (Fixed) \\
\hline 9793 & 4 & $\begin{array}{l}\text { v4.0 UTE 1: 7122: GUI opens offset to Start Window and should } \\
\text { not. }\end{array}$ & Closed (Fixed) \\
\hline 9798 & 5 & $\begin{array}{l}\text { v4.0 UTE 1: W\&E: Add all extensions and waivers to the } 759 \\
\text { part } 4\end{array}$ & Closed (Fixed) \\
\hline 9706 & 4 & $\begin{array}{l}\text { v4.0 UTE 1: (TR17) - CTL Template } 3000 \text { Series Task label } \\
\text { correction. }\end{array}$ & Closed (OBE) \\
\hline 9712 & 3 & $\begin{array}{l}\text { v4.0 UTE 1: (TR 33) - CTL Template: need confirmation of save } \\
\text { of template }\end{array}$ & Closed (OBE) \\
\hline 9752 & 5 & $\begin{array}{l}\text { v4.0 UTE 1: (TR97) - } 7122 \text { Add event text for RL Progression - } \\
\text { "must progress to next RL by }<90 \text { day date from now }>\end{array}$ & Closed (OBE) \\
\hline 9704 & -1 & V4.0 UTE 1: (TR14) - UIC Description standardization & Closed (WAD) \\
\hline 9713 & 5 & $\begin{array}{l}\text { v4.0 UTE 1: (TR 39) - Creating a DA } 4186 \text { will trigger a } 7122 \\
\text { Event entry }\end{array}$ & Closed (WAD) \\
\hline 9716 & -1 & $\begin{array}{l}\text { v4.0 UTE 1: (TR 35) - New GUI's (7120, CTL Template, and } \\
\text { 7122) do not open all on visible window. }\end{array}$ & Closed (WAD) \\
\hline 9733 & -1 & $\begin{array}{l}\text { v4.0 UTE } 1 \text { (TR 74) - MWS: Remove a person from working set } \\
\text { is not intuitive at all. }\end{array}$ & Closed (WAD) \\
\hline 9738 & 5 & $\begin{array}{l}\text { v4.0 UTE 1: (TR03) - } 7122 \text { DA Form Page } 2 \text { need to add crew } \\
\text { member information }\end{array}$ & Closed (WAD) \\
\hline 9744 & -1 & $\begin{array}{l}\text { v4.0 UTE 1: (TR102) - CAC registration not allowed for Foreign } \\
\text { Military (FMs) in TRADOC }\end{array}$ & Closed (WAD) \\
\hline 9754 & 5 & $\begin{array}{l}\text { v4.0 UTE 1: (TR 94) - } 7122 \text { Remove duplicate Evals from the } \\
\text { standard eval list }\end{array}$ & Closed (WAD) \\
\hline 9762 & -1 & $\begin{array}{l}\text { v4.0 UTE 1: (TR 62) - Add CM initial menu option like the CDR } \\
\text { sign }\end{array}$ & Closed (WAD) \\
\hline 9764 & -1 & $\begin{array}{l}\text { v4.0 UTE 1: (TR 67) - } 7122 \text { change tab order when entering an } \\
\text { event }\end{array}$ & Closed (WAD) \\
\hline 9777 & -1 & $\begin{array}{l}\text { V4.0 UTE 1: (TR 59) - DA 7120: Do not need for long remarks to } \\
\text { be pushed from the 7120-R and 7120-1 to the 7120-3. }\end{array}$ & Closed (WAD) \\
\hline 9782 & 5 & $\begin{array}{l}\text { v4.0 UTE 1: (TR 84) -- DA 7120-R: Don't allow selection of } \\
\text { impossible combinations (eg: PI/PC/MP) on the station } \\
\text { selections. }\end{array}$ & Closed (WAD) \\
\hline 9734 & 5 & $\begin{array}{l}\text { v4.0 UTE } 1 \text { (TR 100) } \\
\text { DecertifiedCloseout_WhatCanBeChangedPosted }\end{array}$ & $\begin{array}{l}\text { Open, assigned } \\
\text { to Doss, } \\
\text { Katherine }\end{array}$ \\
\hline 9699 & -1 & $\begin{array}{l}\text { V4.0 UTE 1: (TR 02) - } 7122 \text { Crew member initial events before } \\
\text { they take affect }\end{array}$ & $\begin{array}{l}\text { Open, assigned } \\
\text { to Reece, Don }\end{array}$ \\
\hline
\end{tabular}




\begin{tabular}{|c|c|c|c|}
\hline 9702 & 5 & v4.0 UTE 1: (TR 09) - 7122 Delayed Commander Signature & $\begin{array}{l}\text { Open, assigned } \\
\text { to Reece, Don }\end{array}$ \\
\hline 9715 & 5 & $\begin{array}{l}\text { v4.0 UTE 1: (TR43) - } 7122 \text { Remark for event type 'Assignment' } \\
\text { should auto-populate data within the remark text from Person } \\
\text { Editor }\end{array}$ & $\begin{array}{l}\text { Open, assigned } \\
\text { to Reece, Don }\end{array}$ \\
\hline 9728 & -1 & $\begin{array}{l}\text { v4.0 UTE 1: (TR 55) - DA 7120-1: CAFRS needs to disable tasks } \\
\text { and/or text fields that do not apply to prevent data from being } \\
\text { entered in the wrong text field. }\end{array}$ & $\begin{array}{l}\text { Open, assigned } \\
\text { to Reece, Don }\end{array}$ \\
\hline 9739 & 4 & $\begin{array}{l}\text { v4.0 UTE 1: (TR06) - } 7122 \text { when adding/editing multiple events, } \\
\text { clicking saving should cause a simultaneous update to events } \\
\text { listed on the Events tabs }\end{array}$ & $\begin{array}{l}\text { Open, assigned } \\
\text { to Reece, Don }\end{array}$ \\
\hline 9740 & 4 & $\begin{array}{l}\text { V4.0 UTE 1: (TR22) - } 7122 \text { when adding events should } \\
\text { automatically select the crew member's primary aircraft }\end{array}$ & $\begin{array}{l}\text { Open, assigned } \\
\text { to Reece, Don }\end{array}$ \\
\hline 9742 & 5 & $\begin{array}{l}\text { v4.0 UTE 1: (TR23) - } 7122 \text { Retain Duty Position when creating } \\
\text { multiple events }\end{array}$ & $\begin{array}{l}\text { Open, assigned } \\
\text { to Reece, Don }\end{array}$ \\
\hline 9743 & 4 & $\begin{array}{l}\text { v4.0 UTE 1: (TR28) - } 7122 \text { Add a Duty Position dropdown to } \\
\text { select from for person recording the event. }\end{array}$ & $\begin{array}{l}\text { Open, assigned } \\
\text { to Reece, Don }\end{array}$ \\
\hline 9746 & 5 & $\begin{array}{l}\text { v4.0 UTE 1: (TR42) - } 7122 \text { Need a method for correcting } \\
\text { qualification date information using } 7122 \text { entries }\end{array}$ & $\begin{array}{l}\text { Open, assigned } \\
\text { to Reece, Don }\end{array}$ \\
\hline 9747 & 5 & $\begin{array}{l}\text { v4.0 UTE 1: (TR 04) - DA 7120-R: FAC Level can be changed } \\
\text { through personnel editor aviation personnel data tab even } \\
\text { after the CDR has signed DA Form } 7120\end{array}$ & $\begin{array}{l}\text { Open, assigned } \\
\text { to Reece, Don }\end{array}$ \\
\hline 9748 & -1 & $\begin{array}{l}\text { v4.0 UTE 1: (TR49) - } 7120 \text { need ability to assign Additional } \\
\text { aircraft when individual has more then one additional aircraft }\end{array}$ & $\begin{array}{l}\text { Open, assigned } \\
\text { to Reece, Don }\end{array}$ \\
\hline 9755 & 5 & $\begin{array}{l}\text { v4.0 UTE 1: (TR89) - } 7122 \text { Add the Customize Event button to } \\
\text { Add events window }\end{array}$ & $\begin{array}{l}\text { Open, assigned } \\
\text { to Reece, Don }\end{array}$ \\
\hline 9760 & 5 & $\begin{array}{l}\text { v4.0 UTE 1: (TR 21) -- DA 7120: Provide the capability for the } \\
\text { user to maximize all windows (e.g., 7120) to allow data } \\
\text { entry/view data/ edit data without having to scroll through the } \\
\text { window to view/edit/add data. }\end{array}$ & $\begin{array}{l}\text { Open, assigned } \\
\text { to Reece, Don }\end{array}$ \\
\hline 9766 & 4 & $\begin{array}{l}\text { v4.0 UTE 1: (TR 70) -- DA 7120: Delete Key will not change } \\
\text { number of iterations. Only Backspace key works. Should be } \\
\text { able to use both keys. }\end{array}$ & $\begin{array}{l}\text { Open, assigned } \\
\text { to Reece, Don }\end{array}$ \\
\hline 9773 & 4 & $\begin{array}{l}\text { V4.0 UTE 1: (TR 38) -- DA 7120-R: Duties listed in the 7120-R } \\
\text { PART } 2 \text { must have a remark and do not }\end{array}$ & $\begin{array}{l}\text { Open, assigned } \\
\text { to Reece, Don }\end{array}$ \\
\hline 9774 & -1 & $\begin{array}{l}\text { V4.0 UTE 1: (TR 41) - DA 7120: Changed several fields on a } 7120 \\
\text { that is already signed by the commander (ie. FAC level, } \\
\text { Additional and Primary aircraft). }\end{array}$ & $\begin{array}{l}\text { Open, assigned } \\
\text { to Reece, Don }\end{array}$ \\
\hline 9776 & 5 & $\begin{array}{l}\text { V4.0 UTE 1: (TR 50) - DA 7120-R: On Part IV and V Eval periods } \\
\text { should default to last period entered, allow us to copy date } \\
\text { down for all evals. }\end{array}$ & $\begin{array}{l}\text { Open, assigned } \\
\text { to Reece, Don }\end{array}$ \\
\hline 9779 & 4 & $\begin{array}{l}\text { v4.0 UTE 1: (TR 66) -- DA 7120-1: IPs know task names but not } \\
\text { numbers, can type ahead work on both numbers and task } \\
\text { name parts? }\end{array}$ & $\begin{array}{l}\text { Open, assigned } \\
\text { to Reece, Don }\end{array}$ \\
\hline 9799 & -1 & $\begin{array}{l}\text { v4.0 UTE 1: TRADOC Only: Allow corrections to quals prior to } \\
\text { graduation. }\end{array}$ & $\begin{array}{l}\text { Open, assigned } \\
\text { to Reece, Don }\end{array}$ \\
\hline
\end{tabular}




\begin{tabular}{|c|c|l|l|}
\hline 9829 & 5 & v4.0 UTE 1 CTL Template: Add 7120-3 to template creation. & $\begin{array}{l}\text { Open, assigned } \\
\text { to Reece, Don }\end{array}$ \\
\hline 9830 & 5 & $\begin{array}{l}\text { v4.0 UTE 1: DA 7120-3 apply template should include new -3 } \\
\text { template remarks }\end{array}$ & $\begin{array}{l}\text { Open, assigned } \\
\text { to Reece, Don }\end{array}$ \\
\hline 9759 & 5 & $\begin{array}{l}\text { v4.0 UTE 1: (TR 20) -- DA 7120-R: Default Annual Period to } \\
\text { Birth month. }\end{array}$ & $\begin{array}{l}\text { Open, assigned } \\
\text { to Roberts, } \\
\text { Phillip }\end{array}$ \\
\hline 9770 & 4 & $\begin{array}{l}\text { v4.0 UTE 1: (TR 48) -- DA 7120: Remarks are not in numerical } \\
\text { order. }\end{array}$ & $\begin{array}{l}\text { Open, assigned } \\
\text { to Roberts, } \\
\text { Phillip }\end{array}$ \\
\hline 9735 & 5 & $\begin{array}{l}\text { v4.0 UTE 1 (TR 103) - Graduation, identify what event should } \\
\text { be posted at grad to IERW 7122 }\end{array}$ & $\begin{array}{l}\text { Open, assigned } \\
\text { to Williams, } \\
\text { Paul F }\end{array}$ \\
\hline 9731 & 3 & $\begin{array}{l}\text { v4.0 UTE 1: (TR 12) -- DA 7120-R: Prorate against a 12 month } \\
\text { year is removing one month's hours and should not. }\end{array}$ & $\begin{array}{l}\text { Released to } \\
\text { Testing, } \\
\text { assigned to } \\
\text { Roberts, Brad S }\end{array}$ \\
\hline 5708 & 5 & $\begin{array}{l}\text { v4.0 UTE 1: (TR 57) - ATP Reports -- closeouts ready to sign } \\
\text { v4.0 UTE 1: (Multiple) - 7122 Corrections required for event }\end{array}$ & $\begin{array}{l}\text { Released to } \\
\text { Testing, } \\
\text { assigned to } \\
\text { Smith, Tracy }\end{array}$ \\
\hline & 5 & $\begin{array}{l}\text { Released to } \\
\text { Testing, } \\
\text { assigned to } \\
\text { Wells-Whitted, } \\
\text { Davina }\end{array}$ \\
\hline
\end{tabular}




\section{List of Symbols, Abbreviations, and Acronyms}

\begin{tabular}{|c|c|}
\hline ACFRS & Aviation Center Flight Records System \\
\hline AFRS & Automated Flight Records System \\
\hline ARNG & Army National Guard \\
\hline ARL & US Army Research Laboratory \\
\hline ATS & air traffic services \\
\hline ATM & air traffic management \\
\hline ATS & air traffic services \\
\hline CAC & common access card \\
\hline CAFRS & Centralized Aviation Flight Records System \\
\hline $\mathrm{CCDB}$ & CAFRS Central Database \\
\hline $\mathrm{CDCP}$ & CAFRS Data Collection Point \\
\hline CTL & commander's task list \\
\hline $\mathrm{CW}$ & chief warrant \\
\hline DA & Department of the Army \\
\hline FORSCOM & US Army Forces Command \\
\hline HRED & Human Research and Engineering Directorare \\
\hline IATF & individual aviation training folder \\
\hline $\mathrm{NCO}$ & noncommissioned officer \\
\hline RL & readiness level \\
\hline SFC & sergeant first class \\
\hline SGT & sergeant \\
\hline SSG & staff sergeant \\
\hline TRADOC & US Army Training and Doctrine Command \\
\hline UAS & unmanned aircraft system \\
\hline
\end{tabular}


ULLS-A Unit Level Logistics System-Aviation

UTE User Test Event 


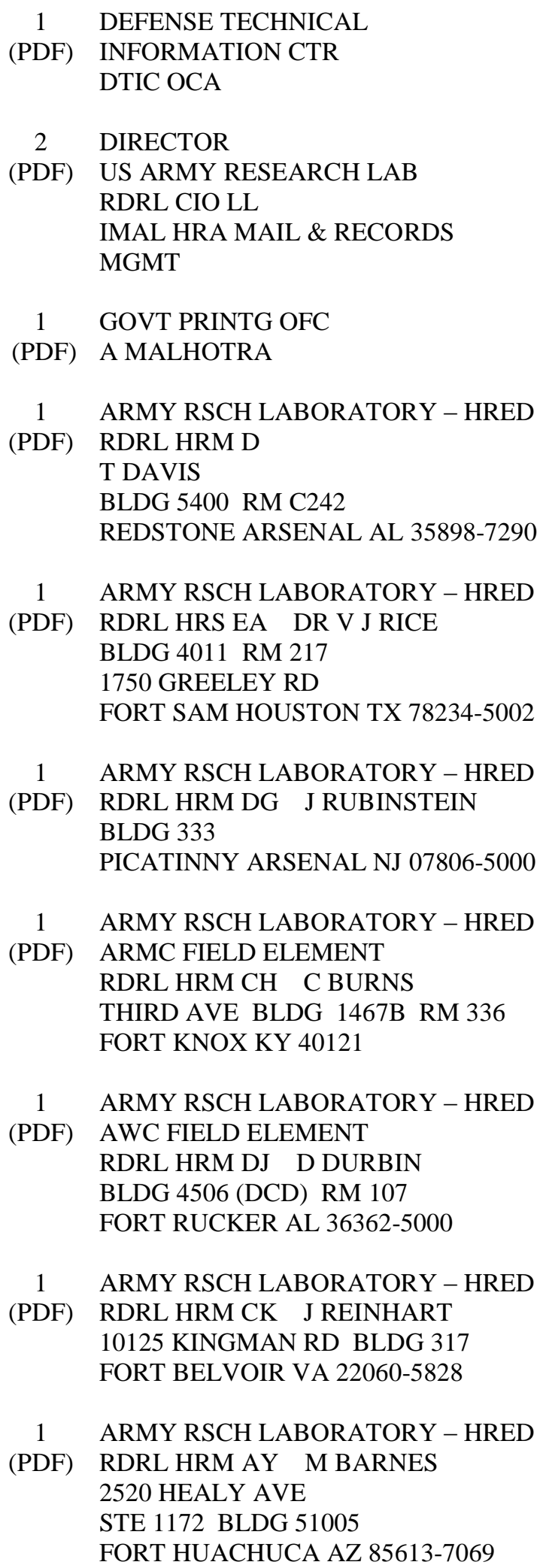

$\begin{array}{cl}1 & \text { ARMY RSCH LABORATORY - HRED } \\ \text { (PDF) } & \text { RDRL HRM AP D UNGVARSKY } \\ & \text { POPE HALL BLDG 470 } \\ & \text { BCBL 806 HARRISON DR } \\ & \text { FORT LEAVENWORTH KS 66027-2302 }\end{array}$
1 ARMY RSCH LABORATORY - HRED
(PDF) RDRL HRM AR J CHEN 12423 RESEARCH PKWY
ORLANDO FL 32826-3276
1 ARMY RSCH LAB - HRED
(PDF) HUMAN SYSTEMS INTEGRATION ENGR TACOM FIELD ELEMENT RDRL HRM CU P MUNYA 6501 E 11 MILE RD MS 284 BLDG 200A WARREN MI 48397-5000
1 ARMY RSCH LABORATORY - HRED
(PDF) FIRES CTR OF EXCELLENCE FIELD ELEMENT RDRL HRM AF C HERNANDEZ 3040 NW AUSTIN RD RM 221 FORT SILL OK 73503-9043

1 ARMY RSCH LABORATORY - HRED (PDF) RDRL HRM AV W CULBERTSON 91012 STATION AVE FORT HOOD TX 76544-5073

1 ARMY RSCH LABORATORY - HRED

(PDF) RDRL HRM DE A MARES 1733 PLEASONTON RD BOX 3 FORT BLISS TX 79916-6816

8 ARMY RSCH LABORATORY - HRED

(PDF) SIMULATION \& TRAINING TECHNOLOGY CENTER RDRL HRT COL G LAASE RDRL HRT I MARTINEZ RDRL HRT T R SOTTILARE RDRL HRT B N FINKELSTEIN RDRL HRT G A RODRIGUEZ RDRL HRT I J HART RDRL HRT M C METEVIER RDRL HRT S B PETTIT 12423 RESEARCH PARKWAY ORLANDO FL 32826

\footnotetext{
1 ARMY RSCH LABORATORY - HRED

(PDF) HQ USASOC RDRL HRM CN R SPENCER BLDG E2929 DESERT STORM DRIVE FORT BRAGG NC 28310
} 


$\begin{array}{cl}1 & \text { ARMY G1 } \\ \text { (PDF) } & \text { DAPE MR B KNAPP } \\ & \text { 300 ARMY PENTAGON RM 2C489 } \\ & \text { WASHINGTON DC 20310-0300 } \\ 12 & \text { DIR USARL } \\ \text { (PDF) } & \text { RDRL HR } \\ & \text { L ALLENDER } \\ & \text { P FRANASZCZUK } \\ \text { K MCDOWELL } \\ \text { RDRL HRM } \\ \text { P SAVAGE-KNEPSHIELD } \\ \text { RDRL HRM AL } \\ \text { C PAULILLO } \\ \text { RDRL HRM B } \\ \text { J GRYNOVICKI } \\ \text { RDRL HRM C } \\ \text { L GARRETT } \\ \text { RDRL HRM DJ } \\ \text { H HARTNETT } \\ \text { RDRL HRS } \\ \text { J LOCKETT } \\ \text { RDRL HRS B } \\ \text { M LAFIANDRA } \\ \text { RDRL HRS D } \\ \text { A SCHARINE } \\ \text { RDRL HRS E } \\ \text { D HEADLEY }\end{array}$

